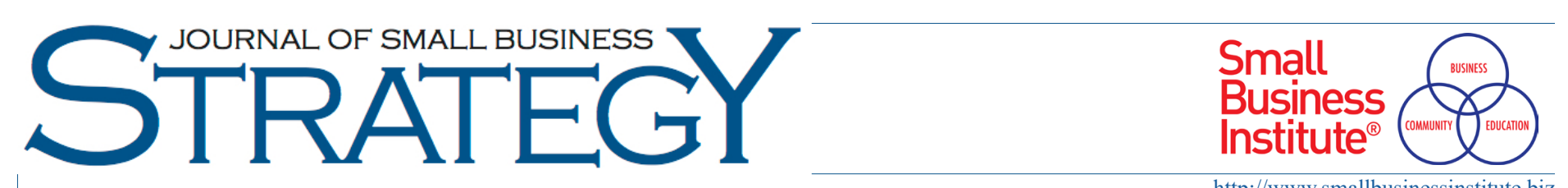

http://www.smallbusinessinstitute.biz

\title{
Entrepreneurial passion: A systematic review and research opportunities
}

\author{
Younggeun Lee ${ }^{1}$, Pol Herrmann ${ }^{2}$ \\ ${ }^{1}$ College of Business and Economics, California State University, Los Angeles, CA 90032, USA, ylee16@calstatela.edu \\ ${ }^{2}$ Ivy College of Business, Iowa State University, Ames, IA 50011, USA, pol@iastate.edu
}

www.jsbs.org

Keywords:

Entrepreneurial passion, Passion for work, Dualistic model of passion, Perceived passion, Systematic review

\section{A B S T R A C T}

In this paper, we conduct a systematic review on the topic of entrepreneurial passion. We summarize the empirical findings of studies based on the four major conceptualizations of passion: passion for work, the dualistic model of passion, entrepreneurial passion, and perceived passion. Moreover, we analyze 63 published papers in the literature and identify potential research opportunities in this area. First, research on the relationship between entrepreneurial passion and firm performance needs further examination; we need comprehensive and more nuanced studies on this relationship, focusing on diverse types of passion. Second, distinctive mechanisms based on different types of passion would enhance our understanding of how passion influences firm performance and other outcomes. Third, it is essential that future studies carefully match theoretical arguments and measurements, based on the frameworks of passion. Fourth, scholars should conduct empirical research on entrepreneurial passion in various cultural contexts. Fifth, theoretical justifications and contextual appropriateness for each framework of passion are critical to advance the literature. Lastly, scholars need to utilize unified terminologies of passion.

\section{Introduction}

Passion is associated with feelings of love (Reis \& Aron, 2008; Sternberg, 1986). Passionate people have specific domains they fall in love with as in romantic relationships or even work activities. Schumpeter (1951) articulated passion as "an important factor of success and social ascent in every walk of life" (p. 177), and Bird (1989) argued that entrepreneurs are "passionate, full of emotional energy, drive, and spirit" (pp. 7-8). Moving beyond general passion, the concept of entrepreneurial passion has received scholarly attention during the past decade and a diverse theoretical framework on entrepreneurial passion has been established, which includes: passion for work (Baum et al., 2001), the dualistic model of passion (Vallerand et al., 2003), entrepreneurial passion (Cardon et al., 2009), and perceived passion (Chen et al., 2009).

In this paper, we aim to synthesize those frameworks by conducting a systematic review on the topic of entrepreneurial passion. We used 'entrepreneurial passion' as the overarching term because it has been continuously utilized

Journal of Small Business Strategy

2021, Vol. 31, No. 03, 122-147

ISSN: 1081-8510 (Print) 2380-1751 (Online)

(C) Copyright 2021 Small Business Institute ${ }^{\circledR}$ to refer diverse domains of passion in the entrepreneurship literature (e.g., Cardon, Glauser, \& Murnieks, 2017a). Moreover, we tracked the seminal papers on four major frameworks of passion and used their originally suggested terminologies for each domain.

Despite the increasing attention on the topic, the literature is fragmented, and scholars have utilized frameworks of passion in entrepreneurship research in different directions. Also, there have been few discussions on prior attempts to synthesize the entrepreneurial passion literature. Our paper aims to provide a comprehensive review to understand the current status of studies on entrepreneurial passion according to four main frameworks of passion. First, we review the literature and summarize the main findings on the different conceptualizations of passion. Specifically, we articulate academic definitions and review theoretical and empirical works based on each framework of passion. Moreover, we compare the similarities and differences between the dualistic model of passion (Vallerand et al., 2003) and entrepreneurial passion (Cardon et al., 2009). Second, we identify what has been done, what we need to know, and what we do not know yet about entrepreneurial passion. Specifically, we found and analyzed 63 published papers in the entrepreneurial passion literature and detected potential

APA Citation Information: Lee, Y., \& Herrmann, P. (2021). Entrepreneurial passion: A systematic review and research opportunities. Journal of Small Business Strategy, 31(3), 122-147. 
areas that could be further investigated.

First, current studies on the relationship between entrepreneurial passion and firm performance are limited to certain types of entrepreneurial passion. Moreover, there are contradictory empirical findings between the dualistic model of passion and firm performance (e.g., Ho \& Pollack, 2014; Patel et al., 2015; Sirén et al., 2016). Therefore, we need comprehensive and more nuanced studies on the relationship between entrepreneurial passion and firm performance. Second, distinctive mechanisms that explain the connection between each type of passion and firm performance need further examination. Third, scholars need to carefully match the theoretical arguments and measurements based on the frameworks of entrepreneurial passion. Fourth, empirical research of entrepreneurial passion should be applied in various cultural contexts. Fifth, different theoretical arguments and contexts need to be considered for each framework of passion to advance the literature. Lastly, scholars should utilize exact terms of passion, as established in the seminal papers.

\section{Literature Review}

Entrepreneurial passion has been studied from different theoretical perspectives: passion for work (Baum et al., 2001), the dualistic model of passion (Vallerand et al., 2003), entrepreneurial passion (Cardon et al., 2009), and perceived passion (Chen et al., 2009). We analyze the literature following the idea that the decision between frameworks should be determined by research questions and by the different conceptualizations of passion (Collewaert et al., 2016; Ho \& Pollack, 2014; Murnieks et al., 2014). We further explain specific definitions, theoretical arguments, and empirical findings of entrepreneurial passion based on each theoretical framework.

\section{Passion for Work}

Early research examined passion for work in the entrepreneurship context (Baum \& Locke, 2004; Baum et al., 2001). Baum and his colleagues defined passion as "love of one's work" (Baum \& Locke, 2004, p. 588) or "selfish love of the work" (Shane et al., 2003, p. 268) and assumed passion as a stable trait that sustains over time. Based on the depictions of entrepreneurs by Locke (1993), Baum and Locke (2004) established five survey items on passion for work. Baum et al. (2001) empirically studied that entrepreneur-CEOs' passion for work indirectly leads to sales, employment, and profit growth through general competencies (i.e., organization and opportunity skill), specific competencies (i.e., industry and technical skill), motivation (i.e., vision, goals, and self-efficacy), and competitive strategies (i.e., differentiation through innovation and quality/ service). Baum and Locke (2004) extended this work and found that entrepreneur-CEOs' passion for work is indirectly related to venture growth through communicated vision, goals, and self-efficacy. Both studies examined the impact of passionate entrepreneurs who love their work and found that passion for work indirectly leads to sales and employment growth through different mediators. De Clercq et al. (2013) utilized this framework and found that passion for work is positively associated with entrepreneurial intentions. They empirically found that passion for work strengthens the perceived ability-entrepreneurial intentions and the perceived attractiveness-entrepreneurial intentions relationships. Baum and his colleagues advanced the entrepreneurship literature by adopting passion into the entrepreneurship domain, by developing theoretical arguments of passion as a trait-based approach, by providing empirical evidence of the positive relationship between passion and firm growth, and by establishing the survey items of passion for work. Figure 1 presents the outcome variables utilized in prior empirical research on passion for work.

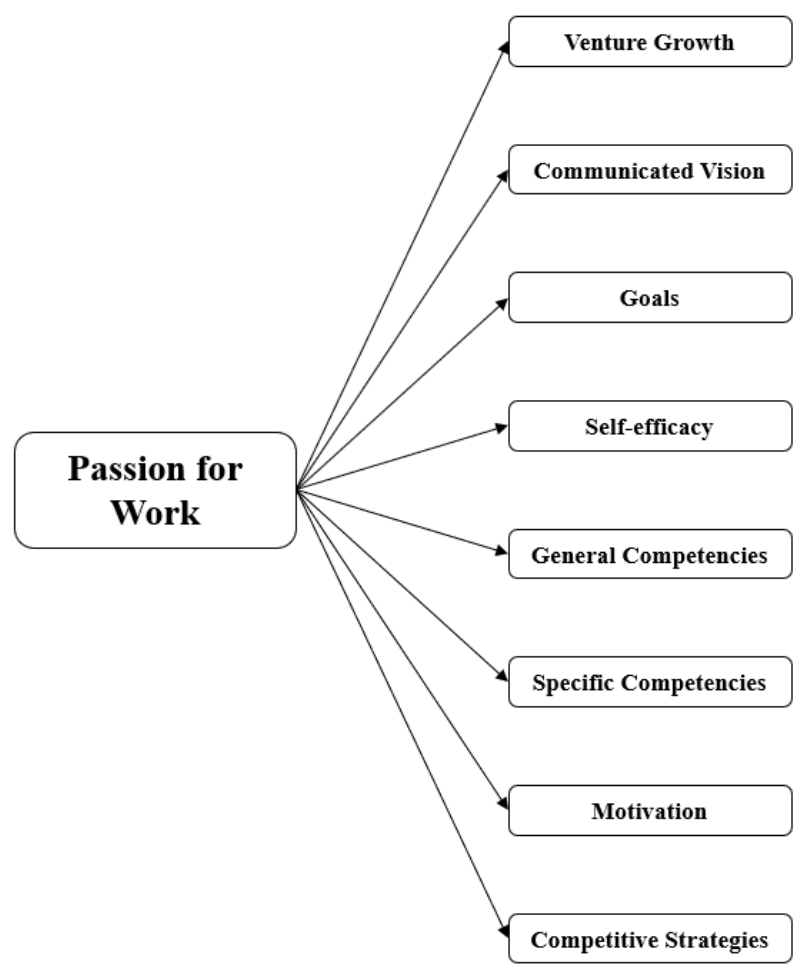

Figure 1. Outcome Variables of Passion for Work

Dualistic Model of Passion - Harmonious and Obsessive Passion

Vallerand et al. (2003) proposed the framework of 
the dualistic model of passion. They defined passion as "a strong inclination toward an activity that people like, that they find important, and in which they invest time and energy" (p. 757) and suggested two types of passion - harmonious and obsessive. Harmonious passion is "an autonomous internalization that leads individuals to choose to engage in the activity that they like" and obsessive passion is "a controlled internalization of an activity in one's identity that creates an internal pressure to engage in the activity that the person likes" (Vallerand et al., 2003, p. 756). Vallerand et al. (2003) also established 12 survey items to measure the dualistic model of passion, which has been utilized in different fields and validated across age, gender, language, and activities (Marsh et al., 2013; Vallerand, 2015).

Researchers have applied the dualistic model of passion in the entrepreneurship literature. We summarize below the main empirical findings of this model. Ho and Pollack (2014) found that harmonious entrepreneurial passion indirectly impacts referral and total business income through increased out-degree centrality (i.e., searching for others). Additionally, obsessive entrepreneurial passion negatively influences referral and total business income through decreased levels of in-degree centrality (i.e., less approachable by others). Murnieks et al. (2014) found that harmonious passion is positively associated with entrepreneurial behavior and self-efficacy. Thorgren and Wincent (2015) examined the relationship between entrepreneurs' passion and habitual entrepreneurship and found that obsessive passion is related to both serial (i.e., "engaged in a previous start-up") and portfolio entrepreneurship (i.e., "started another business while running at least one other company", p. 219). However, harmonious passion only impacts portfolio entrepreneurship among habitual entrepreneurship types (Thorgren \& Wincent, 2015). Dalborg and Wincent (2015) examined that entrepreneurs who are "being pulled toward opportunities to start a business" indirectly nurture harmonious passion through self-efficacy (p. 974).

Stroe et al. (2018) found that entrepreneurs with harmonious passion make effectual decision-making when they have high self-efficacy or perceive high risk in the environment, and entrepreneurs with obsessive passion make causal decision-making when they perceive low risk in the environment. In other words, entrepreneurs implement different entrepreneurial decision-making logics depending on their types of passion, under certain conditions. Moreover, Stroe et al. (2018) found that role overload develops nascent entrepreneurs' obsessive passion. Fisher et al. (2018) argued that entrepreneurs' obsessive passion leads to sustained commitment, and harmonious passion influences entrepreneurs to perceive themselves as successful through resilience. De Mol et al. (2018) found that entrepreneurs' job fit leads to higher burnout through obsessive passion, but harmonious passion is negatively associated with burnout.

Schenkel et al. (2019) found that employees' harmonious passion for being entrepreneurial positively influences them to spend more time thinking about new ideas, which then leads them to suggest an increased number of job-related innovative ideas. Obschonka et al. (2019) found that researchers' harmonious entrepreneurial passion is positively associated with entrepreneurial behavior. Murnieks et al. (2020) studied the antecedents of the dualistic model of passion. Specifically, entrepreneurial identity centrality is related to harmonious entrepreneurial passion and affective interpersonal commitment drives obsessive entrepreneurial passion (Murnieks et al., 2020). Moreover, the authors examined the gender of entrepreneurs as the moderator of both relationships and found that male entrepreneurs positively strengthen both relationships. Stroe et al. (2020) examined different moderating roles of harmonious and obsessive passion on the relationship between fear of failure and negative effect. Entrepreneurs' fear of failure manifests negative effect and harmonious passion reduces this influence; however, obsessive passion shows both positive and negative moderating effects on this relationship in two different studies (Stroe et al., 2020). Figure 2 and 3 display the antecedent and outcome variables found in prior empirical research on the dualistic model of passion.

\section{Entrepreneurial Passion - Inventing, Developing, and Founding Passion}

Cardon et al. (2009) introduced a framework of entrepreneurial passion based on certain roles of entrepreneurs. Entrepreneurial passion is defined as "consciously accessible, intense positive feelings experienced by engagement in entrepreneurial activities associated with roles that are meaningful and salient to the self-identity of the entrepreneur" (Cardon et al., 2009, p. 517). Based on the categorization of entrepreneurial activities (Gartner et al., 1999), Cardon et al. (2009) suggested three distinct entrepreneurial role identities: inventing, developing, and founding passion. Specifically, inventing passion is associated with "identifying, inventing, and exploring new opportunities"; developing passion is related to "nurturing, growing, and expanding the venture"; founding passion involves "establishing a venture for commercializing and exploiting opportunities" (Cardon et al., 2009, p. 516).

Cardon and colleagues' (2009) framework of entrepreneurial passion has been spread widely in the entrepreneurship field and their establishment of survey items of inventing, developing, and founding passion ignited the empirical research on entrepreneurial passion. Specifically, Cardon 


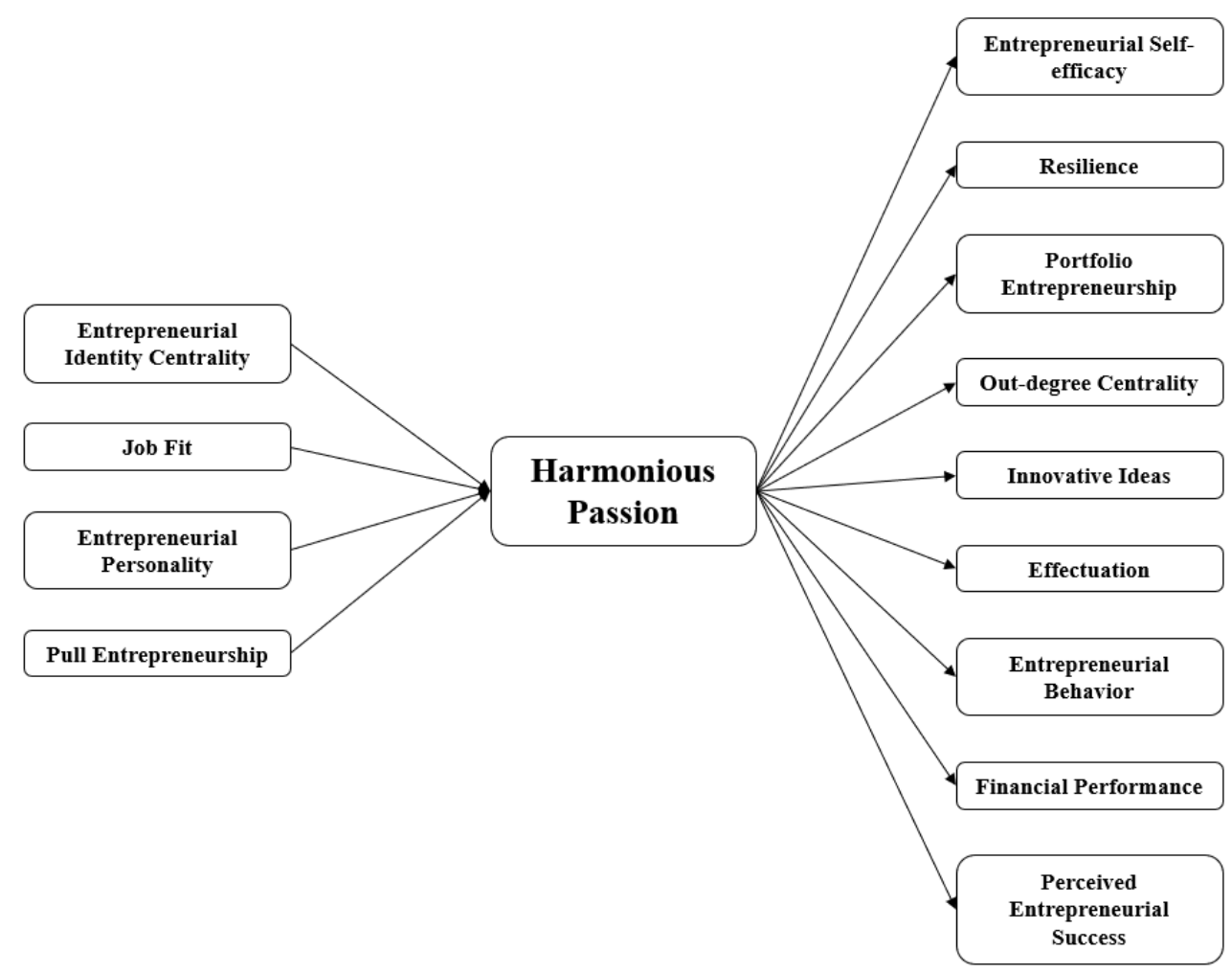

Figure 2. Antecedent and Outcome Variables of Harmonious Passion

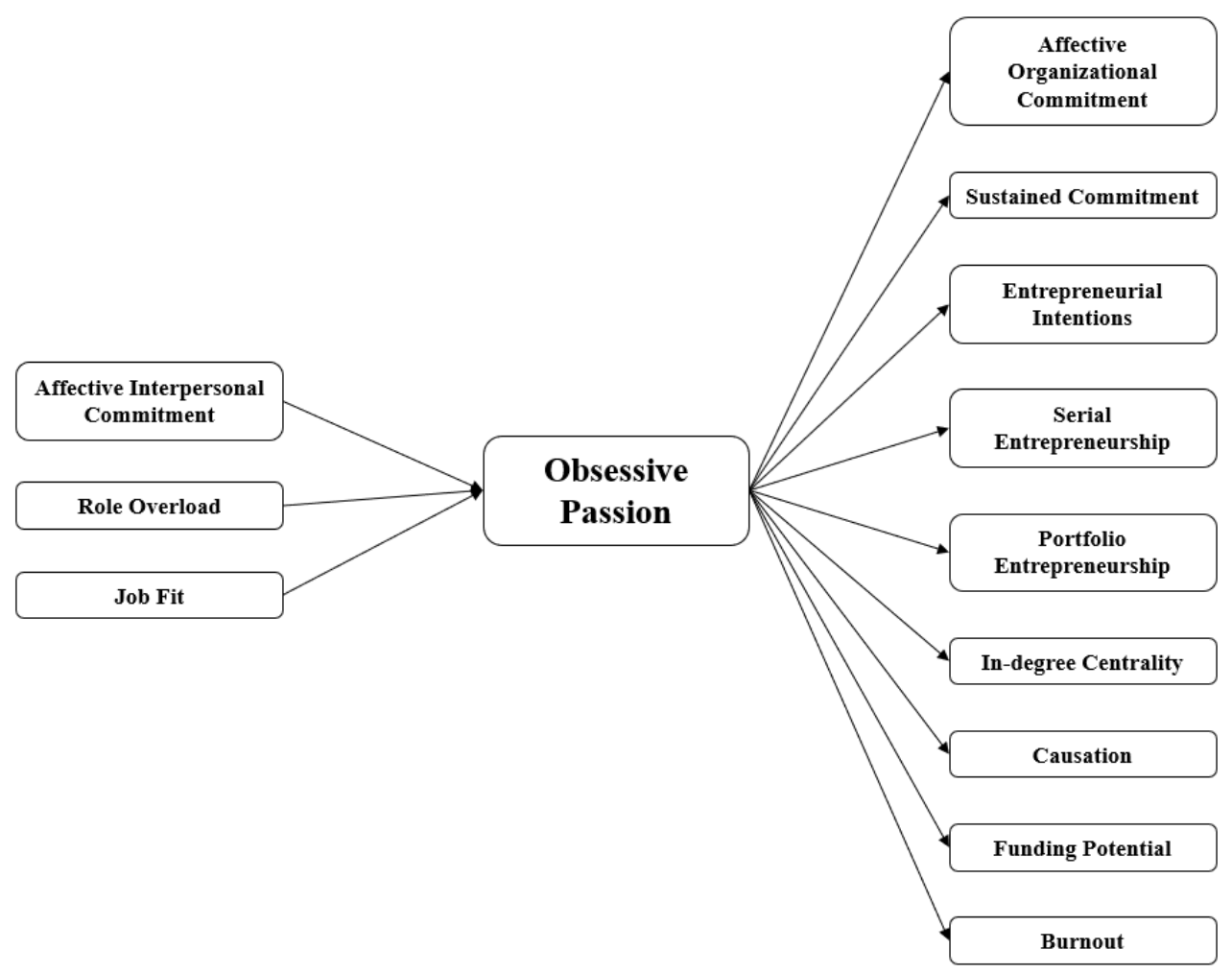

Figure 3. Antecedent and Outcome Variables of Obsessive Passion 
et al. (2013) established 13 survey items of entrepreneurial passion, which include five items for inventing passion, four items for developing passion, and four items for founding passion. Following Cardon and colleagues' (2009) conceptualization, authors divided each passion into two dimensions: intensive positive feelings and identity centrality. To operationalize each passion, Cardon et al. (2013) recommend using formative measurement. In other words, items for intensive positive feelings need to be averaged and multiplied with one identity centrality item to calculate each passion. They also suggest not to combine all three domains as one entrepreneurial passion construct.

Cardon et al. (2013) not only developed the survey items of entrepreneurial passion, but also empirically found that entrepreneurial passion for founding is associated with creativity and persistence. Moreover, entrepreneurial passion for developing is positively linked to absorption (Cardon et al., 2013). Cardon and Kirk (2015) empirically found that entrepreneurial self-efficacy indirectly increases persistence through inventing and founding passion. Stenholm and Renko (2016) researched that entrepreneurial passion for inventing and developing indirectly leads to new venture survival through bricolage.

Kang et al. (2016) investigated an antecedent (i.e., organizational innovative climate) and an outcome (i.e., employees' innovative behavior) of entrepreneurial passion for inventing. They found that proactive climate positively moderates the relationship between innovative climate and inventing passion, and risk-taking climate increases the influence of inventing passion on innovative behavior. Huyghe et al. (2016) found that inventing passion increases spin-off and start-up intentions. Drnovsek et al. (2016) empirically examined founder CEOs' passion for developing impact on sales and employee growth. Moreover, goal commitment mediates developing passion-venture growth relationships (Drnovsek et al., 2016). Collewaert et al. (2016) found that entrepreneurial passion for founding diminishes over time. Specifically, intensive positive feelings decrease over time and identity centrality remains stable (Collewaert et al., 2016). Biraglia and Kadile (2017) studied that founding passion positively leads to entrepreneurial intentions and that entrepreneurial self-efficacy acts as a partial mediation in this link.

Mueller et al. (2017) found that entrepreneurs' passion for developing indirectly increases firm performance through self-regulatory mode and grit. Campos (2017) also found that developing passion is positively related to entrepreneurial orientation and that entrepreneurial alertness mediates this relationship. Strese et al. (2018) examined that CEOs' passion for inventing positively increases radical innovation in small and medium-sized enterprises.
Costa et al. (2018) showed that intensive positive feelings toward developing, inventing, and founding role identities positively moderate the impact of cognitive entrepreneurial training on the accuracy of the business opportunity recognition. Karimi (2020) studied that university students' inventing passion positively increases entrepreneurial intentions through either attitudes toward entrepreneurship or perceived behavioral control. Xiao et al. (2020) examined that employees' skill variety positively impacts them to form a team and this influence is strengthened by employees' developing passion.

Cardon, Post et al. (2017) proposed the concept of team entrepreneurial passion (TEP; i.e., "the level of shared intense positive feelings for a collective and central team identity for new venture teams", p. 283). They theoretically explained that team passion diversity would positively influence the formation of team entrepreneurial passion. Moreover, team entrepreneurial passion impacts diverse individual- and team-level outcomes like new venture team performance, quality of new venture team processes, and individual entrepreneurial passion (Cardon. Post et al., 2017). Santos and Cardon (2019) empirically found that TEP for inventing and developing is positively associated with performance of new venture team (NVT). The relationship between TEP for inventing and team performance is moderated by "mono-focal (NVTs with a higher score in one of the domains compared to the others); incomplete poly-focal (NVTs showing higher scores in two of the three domains of TEP); and complete poly-focal (NVTs showing no differences between the scores of the three domains)" (Santos \& Cardon, 2019, p. 10).

Boone et al. (2020) studied new venture teams in different stages and found that, in the commercialization stage, poly-focal team entrepreneurial passion (both high on inventing and founding) is better at achieving high team performance through reduced relationship conflict than mono-focal team entrepreneurial passion (either inventing or founding). De Mol et al. (2020) found that average team passion is not associated with performance. Moreover, entrepreneurial passion diversity (i.e., intensity separation) negatively influences the quality of the business idea, and entrepreneurial passion diversity (i.e., focus variety) negatively impacts the amount of funding that teams will receive (de Mol et al., 2020). Figure 4, 5, and 6 summarize the antecedent and outcome variables examined in prior empirical research on entrepreneurial passion.

Vallerand et al. (2003) dualistic model of passion and Cardon et al. (2009) entrepreneurial passion are similar in the sense that both include affection and identification as core components of passion. Both frameworks argue that entrepreneurial passion is a strong affection for entrepreneurial 
activities that are meaningful to their identities. However, the two frameworks differ in their approach toward entrepreneurship and internalization (Collewaert et al., 2016; Ho \& Pollack, 2014). First, Vallerand et al. (2003) have a general approach toward entrepreneurial passion. Specifically, scholars who want to examine an entrepreneur's overall passion for entrepreneurship activities should adopt the dualistic model of passion (Ho \& Pollack, 2014). Cardon et al. (2009) take a specific approach toward entrepreneurial passion. To elaborate, they assume that entrepreneurs have three specific roles and different levels of affection toward those entrepreneurial roles. Therefore, Cardon et al. (2009) approach is domain-specific, rather than an overall understanding of passion. Second, Vallerand et al. (2003) further elaborate on how entrepreneurial activities are internalized and differentiate harmonious and obsessive passion in terms of autonomous and controlled internalization toward one's identity.

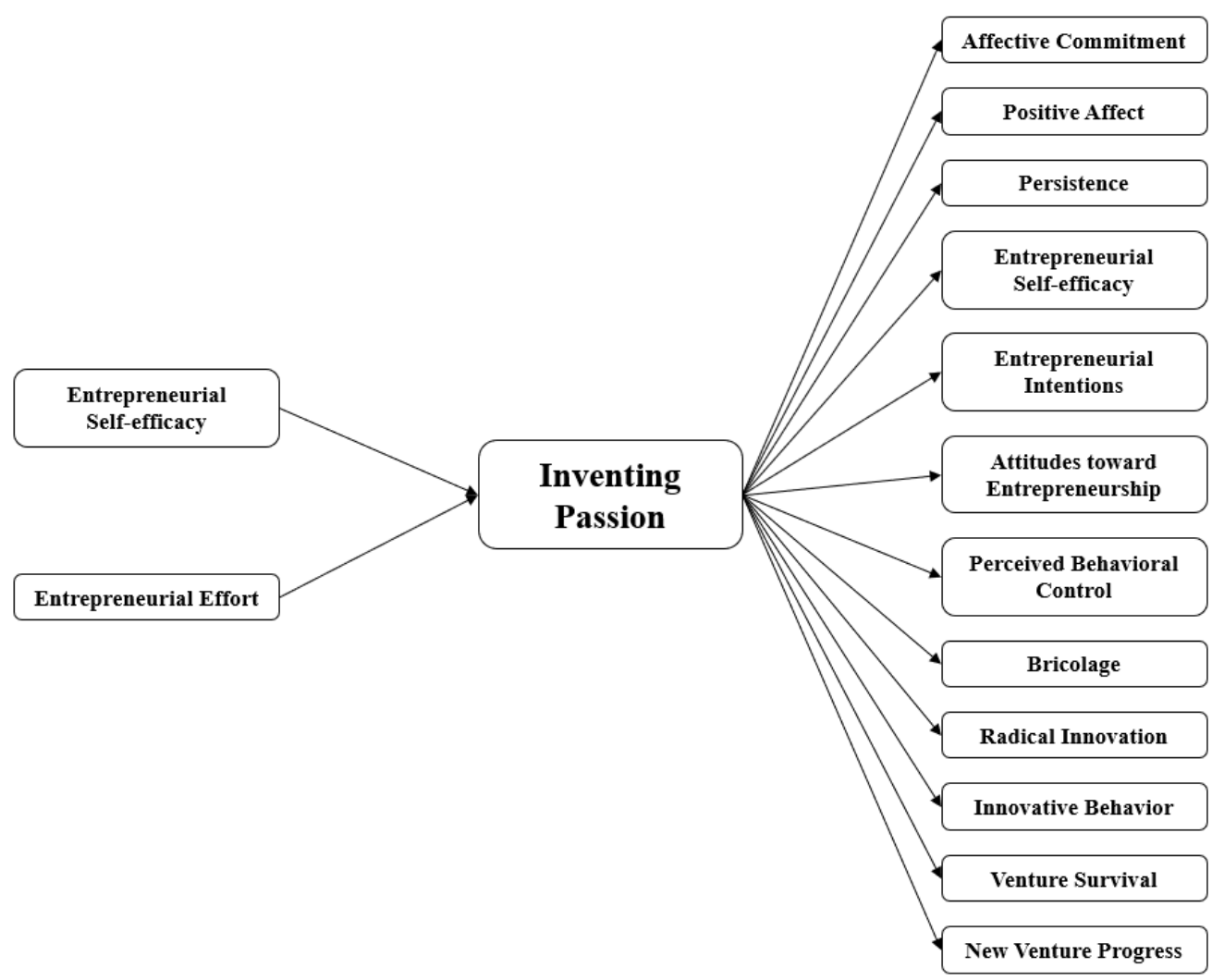

Figure 4. Antecedent and Outcome Variables of Inventing Passion

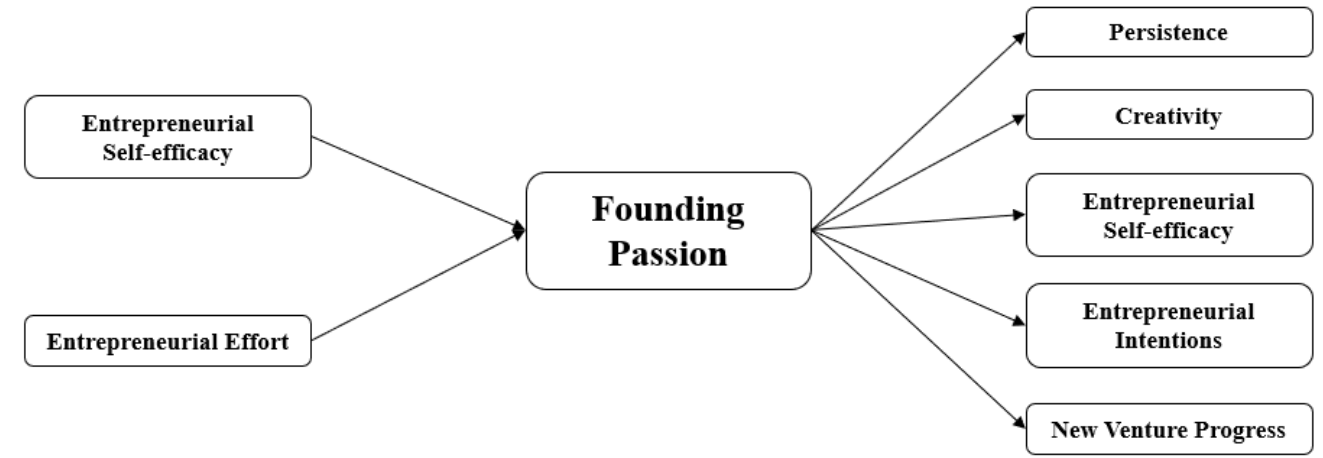

Figure 5. Antecedent and Outcome Variables of Founding Passion 


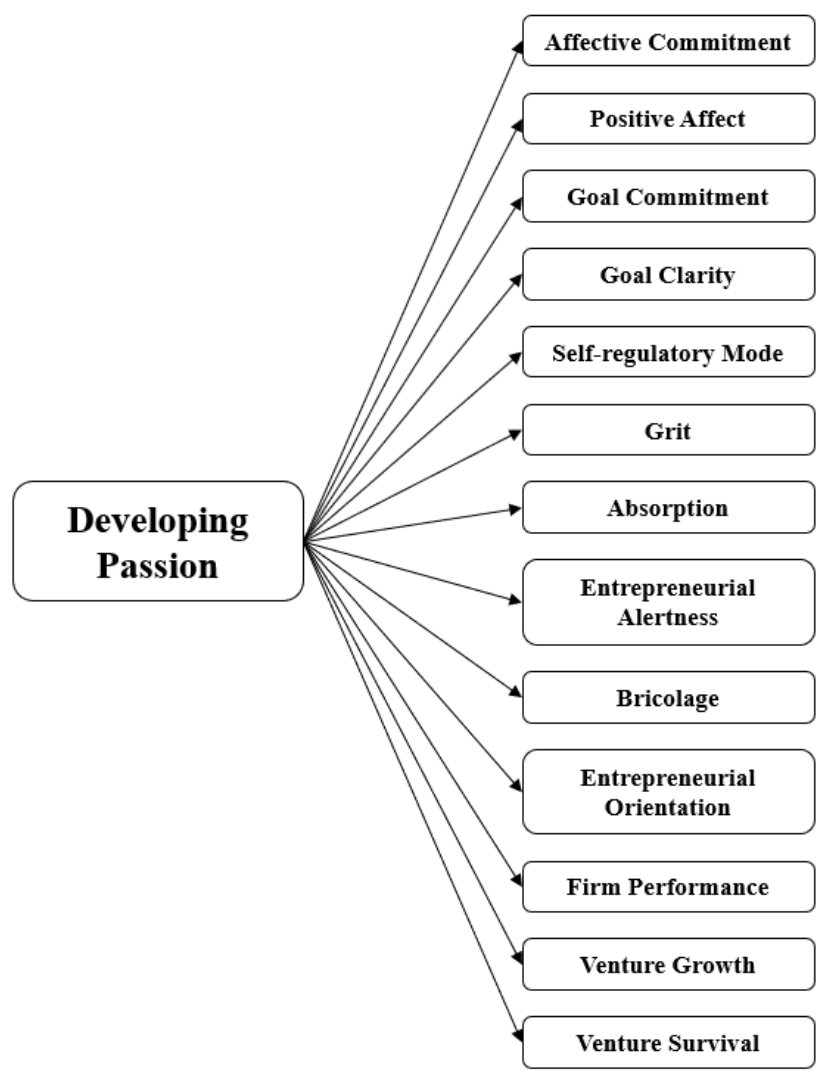

Figure 6. Outcome Variables of Developing Passion

\section{Perceived Passion}

Entrepreneurial finance scholars proposed the concept of perceived passion (Chen et al., 2009). In this area, scholars argue that entrepreneurs' passion is a critical indicator that helps persuade investors to make investment decisions (e.g., Davis et al., 2017; Mitteness et al., 2012). Chen et al. (2009) defined entrepreneurial passion as an "intense affective state accompanied by cognitive and behavioral manifestations of high personal value" (p. 201) and found that entrepreneurs' preparedness in presentations (i.e., perceived cognitive passion) promotes funding from venture capitalists. Also, Chen et al. (2009) established 11 survey items to capture perceived passion. Specifically, six items are about affective passion, which are questions on the body movements, language, gestures, and expressions of presenters. The other five items are about cognitive passion (i.e., preparedness), which are questions on logic, fact, and presentation content.

Scholars have advanced the understanding of perceived passion by examining how diverse investors' (e.g., venture capitalists and angel investors) perceptions of entrepreneurial passion relate to investment, funding, or crowdfunding performance. Empirical findings in this research stream have made significant contributions to our understanding of entrepreneurial passion. Mitteness et al. (2012) utilized 3,502 evaluations of 241 presentations examined by 64 angel investors and found that passion perceived by angel investors positively influences funding potentials. Moreover, angel investors' characteristics like older age, higher intuition, openness, and motivation toward mentor strengthen the perceived passion-funding potential relationship; however, angels who are extraverted and promotion-focused negatively impact the relationship (Mitteness et al., 2012).

Davis et al. (2017) observed that entrepreneurial passion perceived by funders positively moderates the relationship between product creativity and positive affective reactions. Authors found a negative influence of perceived entrepreneurial passion on funders' investment decisions and predicted success (Davis et al., 2017). Li et al. (2017) conducted three studies utilizing surveys and archival data from Indiegogo and Kickstarter and an experiment on 120 MBA students and found that entrepreneurs' displayed passion on crowdfunding video expands the enthusiasm of viewers, which in turn increases funding amount and social media exposure. They also examined the moderating impact of project innovativeness as perceived by viewers, which invigorates both the displayed passion-funding amount and the displayed passion-social media exposure associations (Li et al., 2017). Cardon, Mitteness et al. (2017) used 1,995 
evaluations of 133 presentations completed by 72 angel investors and discovered that evaluations of funding decisions by angel investors are positively associated with entrepreneurs' level of preparedness. When entrepreneurs commit personal money to their idea, prepared entrepreneurs' chance of obtaining positive evaluations on funding has increased (Cardon, Mitteness et al., 2017). In other words, angel investors favor prepared entrepreneurs with personal financial commitment in their idea.

Warnick et al. (2018) employed 992 decisions on 16 hypothetical investment opportunities evaluated by 31 venture capitalists and 31 angel investors and found that angel investors and venture capitalists perceive both entrepreneurial passion and passion for the product as critical factors for investment decisions. Entrepreneurs' openness to feedback positively moderates both types of passion toward funding potential (Warnick et al., 2018). Interestingly, the authors found a three-way interaction among investing experience of investors, openness to feedback, and entrepreneurial passion toward funding potential. Passion for the product also demonstrates a three-way interaction with entrepreneurial experience of investors and openness to feedback toward funding potential; however, a combination of entrepreneurial passion and passion for the product does not predict funding potential (Warnick et al., 2018). Oo et al. (2019) researched that user entrepreneurship leads to crowdfunding performance through perceived passion. Using functional Magnetic Resonance Imaging (fMRI), Shane et al. (2020) empirically found the causal relationship between entrepreneurs' displayed passion and informal investors' interest by analyzing 147 neural responses of 15 informal investors to 20 entrepreneurs' pitches. Figure 7 elucidates the antecedent and outcome variables investigated in prior empirical research on perceived passion.
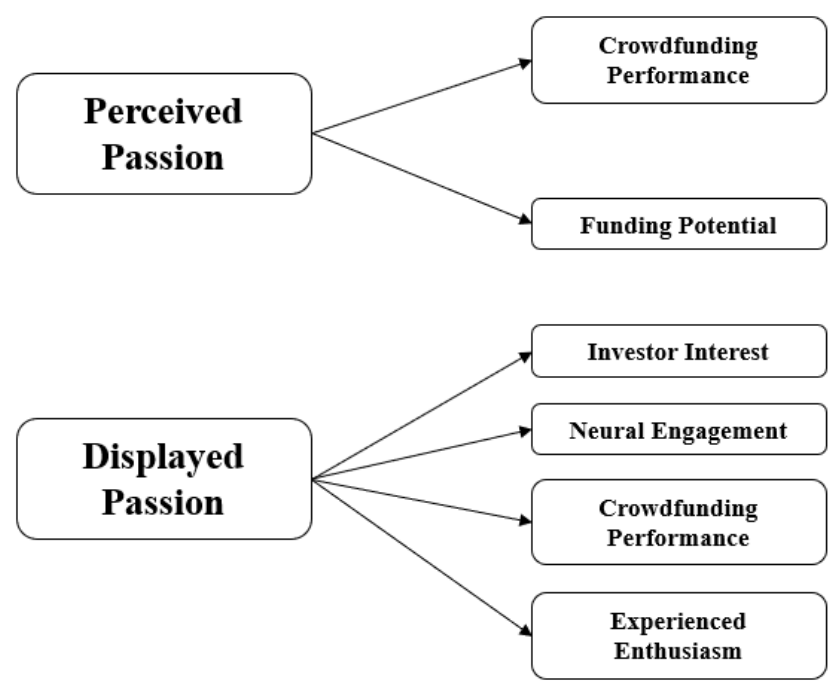

Figure 7. Outcome Variables of Perceived and Displayed Passion

\section{Systematic Review}

To thoroughly understand the current status of studies on entrepreneurial passion, we conducted a systematic review of the journal publications that examined entrepreneurial passion. Specifically, we followed the procedure of previous systematic reviews (e.g., Stephan, 2018; Shepherd et al., 2019; Tranfield et al., 2003). First, we searched an online database (i.e., Web of Science) to find journal publications on entrepreneurial passion between 2001 and January 2020. We aimed for articles that mentioned the term, 'entrepreneurial passion' in the title, abstract, or keywords at peer-reviewed journals including entrepreneurship (e.g., Entrepreneurship Theory and Practice, Journal of Business Venturing, and Strategic Entrepreneurship Journal) and management (e.g., Academy of Management Journal, Academy of Management Review, and Journal of Management). The search yielded 323 papers. Second, we read the abstract of each paper to decide on the inclusion and exclusion of papers in the review. We deleted conference proceedings, duplicated papers, case studies, and articles that studied passion for non-entrepreneurship domains. As a result, we excluded 260 papers and included 63 journal publications.

Table 1 shows the number of publications based on each type of entrepreneurial passion, and Table 2 indicates the number of publications based on each journal. Third, we reviewed each paper thoroughly and coded authors, year of publication, published journal, type of research, type of passion, measurement of passion, variables (i.e., independent, dependent, mediator, and moderator), nature of the sample, country of data collection, theoretical perspectives, and core findings of each paper. We attach the summarized version of coding in the Appendix.

Table 1

Number of publications by types of entrepreneurial passion

\begin{tabular}{lc}
\hline \multicolumn{1}{c}{ Types of Passion } & Publications \\
\hline Entrepreneurial Passion & 27 \\
Dualistic Model of Passion & 16 \\
Perceived Passion & 8 \\
Passion for Work & 3 \\
\hline
\end{tabular}

Note. We also found 10 papers that did not focus on specific types of entrepreneurial passion, but studied passion for overall entrepreneurship. 
The attention on the topic of entrepreneurial passion is increasing as shown by the number of publications (Figure 8). In recent reviews, Murnieks et al. (2014) explained that "to our knowledge, only three published articles have examined passion among entrepreneurs empirically" (p. 1588), and Cardon, Glauser et al. (2017) reviewed journal publications on the topic of entrepreneurial passion and found 29 published papers. Moreover, Murnieks et al. (2020) marked that "our review indicates ... 14 empirical articles which have examined entrepreneurial passion to date" (p. 5). In our systematic review, we found a total of 63 journal publications, of which 9 papers are conceptual and 54 are empirical.

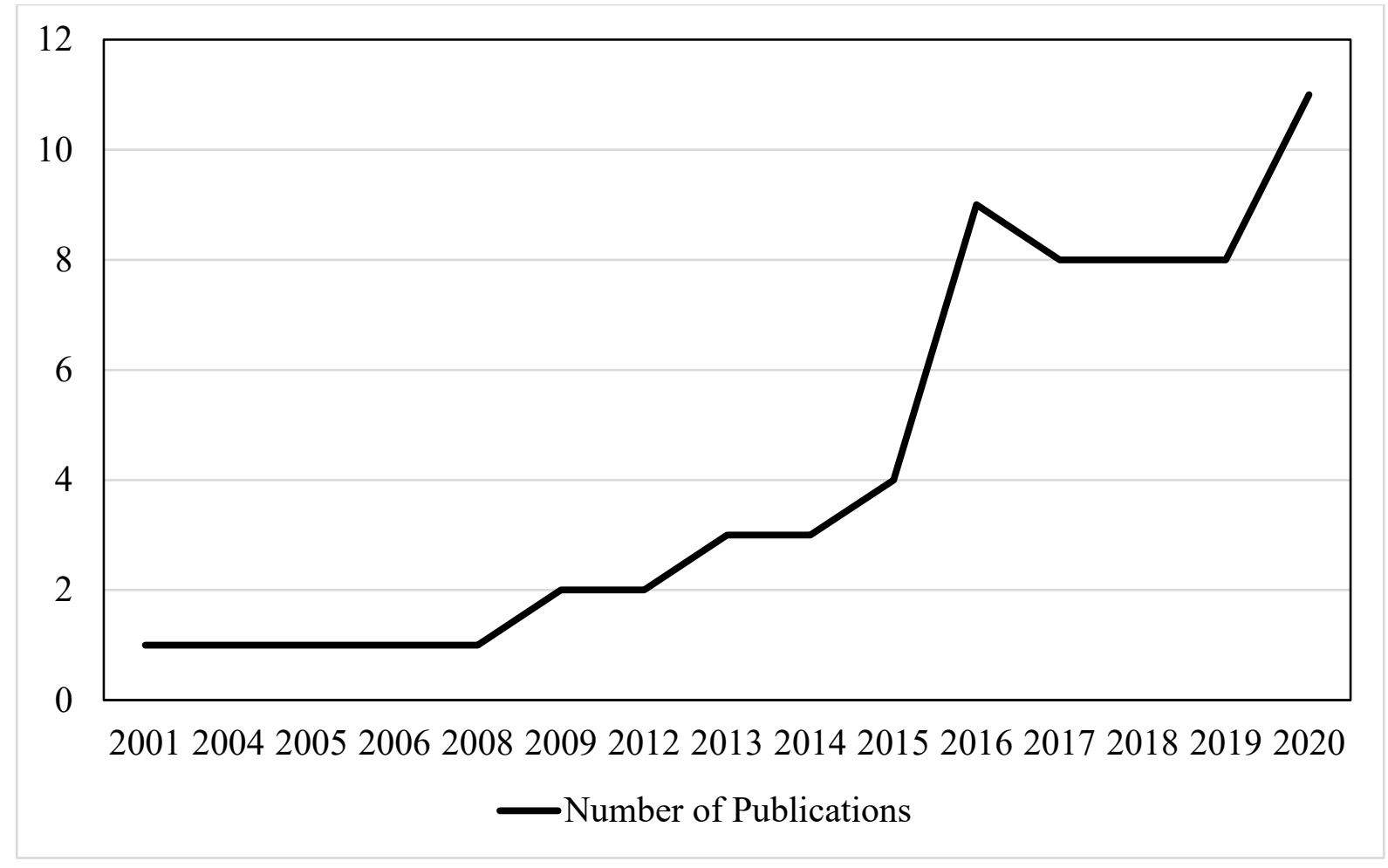

Figure 8. Increasing Scholarship on Entrepreneurial Passion

\section{Future Research Opportunities}

Based on the results of our systematic review on entrepreneurial passion, we discuss areas that could be further advanced according to each framework.

\section{Passion for Work}

Although scholars have continuously applied work passion in diverse areas (Pollack et al., 2020), there is still a lack of studies of work passion in the context of entrepreneurship. As we explained, seminal studies of this framework have motivated researchers to examine entrepreneurs' general work passion (Baum \& Locke, 2004); however, we were only able to find three papers that used the concept in the entrepreneurship literature. Entrepreneurs invest a large amount of time in work, and it is common to find CEOs or investors who love working for their start-ups. As such, scholars could utilize the framework of work passion and study the phenomenon of entrepreneurship to further extend the literature.

\section{Dualistic Model of Passion}

To advance the literature on the dualistic model of passion, we need to understand distinctive antecedents and outcomes of harmonious and obsessive passion. Most studies in the literature examined directional differences of harmonious and obsessive passion on the same outcome. For instance, De Mol et al. (2018) found a positive relationship between obsessive passion and burnout and a negative relationship between harmonious passion and burnout. We believe that extending recent studies that found unique antecedents or outcomes corresponding with harmonious and obsessive passion (Curran et al., 2015; Murnieks et al., 2020; Pollack et al., 2020) and investigating the distinct 
Table 2

Number of publications by journals

\begin{tabular}{|c|c|}
\hline Journal & Publications \\
\hline Journal of Business Venturing & 17 \\
\hline Journal of Small Business Management & 7 \\
\hline Entrepreneurship Theory and Practice & 5 \\
\hline Academy of Management Journal & 3 \\
\hline International Small Business Journal & 3 \\
\hline Journal of Business Research & 3 \\
\hline Academy of Management Review & 2 \\
\hline Frontiers in Psychology & 2 \\
\hline International Journal of Entrepreneurial Behavior and Research & 2 \\
\hline Journal of Applied Psychology & 2 \\
\hline Journal of Management Studies & 2 \\
\hline Applied Economics & 1 \\
\hline Applied Psychology & 1 \\
\hline Entrepreneurship and Regional Development & 1 \\
\hline Entrepreneurship Research Journal & 1 \\
\hline Human Resource Management Review & 1 \\
\hline Journal of Business Venturing Insights & 1 \\
\hline Journal of Entrepreneurship & 1 \\
\hline Journal of Management & 1 \\
\hline Journal of Small Business and Enterprise Development & 1 \\
\hline Journal of Small Business Strategy & 1 \\
\hline Leadership Quarterly & 1 \\
\hline Management Research Review & 1 \\
\hline Strategic Entrepreneurship Journal & 1 \\
\hline Technology Analysis and Strategic Management & 1 \\
\hline Venture Capital & 1 \\
\hline
\end{tabular}

linkages of each type of passion could help accumulate our knowledge in the entrepreneurial passion literature.

For instance, harmoniously passionate people are creative and persistently seek feedback from others (Liu et al., 2011; Sirén et al., 2016), which could be linked to outcomes like bricolage (Baker \& Nelson, 2005), strategic entrepreneurial behavior (Anderson et al., 2019), or entrepreneurial imagination (Kier \& McMullen, 2018). These entrepreneurship concepts are related to creativity and innovativeness, and we suggest scholars research such relationships. Moreover, obsessively passionate people make an effective commitment toward their organizations (Huyghe et al., 2016) and are defensive about their identity (Philippe et al., 2010), which could be linked to outcomes like identity fusion
(Swann, Gómez et al., 2009), risk-taking (Covin \& Slevin, 1989), or competitive aggressiveness (Lumpkin \& Dess, 1996).

\section{Entrepreneurial Passion}

Scholars who apply Cardon et al.'s (2009) framework of entrepreneurial passion need to investigate diverse contexts and not assume that entrepreneurial passion is a concept only applicable to entrepreneurs of small firms. We need to look beyond this prejudice on entrepreneurial passion and utilize the concept in various contexts, which would bring fruitful directions for the literature. Similar to the five-factor model of personality (McCrae \& Costa, 
1987), which was applied to diverse agents with different characteristics such as CEOs (e.g., Herrmann \& Nadkarni, 2014) and entrepreneurs (e.g., Zhao \& Seibert, 2006), entrepreneurial passion is not a characteristic unique to entrepreneurs of small firms, but one that is likely to exist among non-entrepreneurs (e.g., CEOs, employees, professors, students, or politicians) of diverse types of organizations (e.g., large, non-profit, government agencies, universities, or political parties). For instance, professors who expand their research and teaching roles in their affiliated universities could have high developing passion, employees who always enjoy finding completely new tasks would be high on inventing passion, and politicians who establish or join new political parties could be linked to founding passion.

\section{Perceived Passion}

In this area, it is important to clearly distinguish between similar concepts of passion: perceived, displayed, and felt. Perceived passion is observed passion of entrepreneurs that is captured by others like employees, stakeholders, or investors; displayed passion is personal meanings and feelings of passion that are expressed by entrepreneurs (Mitteness et al., 2012). Felt passion refers to entrepreneurs' experienced passion (Shane et al., 2020, p. 8); in other words, it is emotions of passion that entrepreneurs feel themselves. To be clear, "the emotion an entrepreneur displays may not be perceived by the investor" (Mitteness et al., 2012, p. 594). Accordingly, perceived passion is the most appropriate type of passion when examining external observer's perceptions on entrepreneurs' passion (Mitteness et al., 2012) and displayed passion is suitable to study entrepreneurs' self-assessment on their apparent passion (Shane et al., 2020).

Moving beyond each framework, we also identified areas that could potentially advance the overall entrepreneurial passion literature: 1) conducting in-depth and more nuanced studies on the entrepreneurial passion and firm performance relationships, based on various frameworks of passion, 2) examining specific mechanisms that link each type of passion and performance, 3) solving the issue of mismatch between theoretical frameworks and measurement of entrepreneurial passion, 4) applying entrepreneurial passion in different cultural settings, 5) concentrating on the theoretical justifications for each framework of passion, and 6) utilizing unified terminologies of passion.

First, the relationship between entrepreneurial passion and firm performance needs both theoretical and empirical advancement. Firm performance has been a focus of broad management research (Dess \& Robinson, 1984). In the entrepreneurship literature, diverse publications on meta-analysis confirm the importance of performance: entrepreneurial orientation-firm performance (Rauch et al., 2009), personality-entrepreneurial performance (Zhao et al., 2010), innovation-firm performance (Rosenbusch et al., 2011), human capital-entrepreneurial success (Unger et al., 2011), and internationalization-firm performance (Schwens et al., 2018). However, we still lack understanding of the relationship between passion and performance. As such, scholars should give more attention to the performance outcomes of entrepreneurial passion in diverse contexts, using different performance measures, and applying different entrepreneurial passion frameworks to further advance the literature. We need to answer research questions like: What are the financial or organizational benefits of entrepreneurs' passion? What are the mechanisms and contingencies on the relationship between entrepreneurial passion and firm performance?

Based on the analysis of the research stream on the relationship between entrepreneurial passion and firm performance, one main conclusion is that we have much to learn about the financial outcomes of diverse types of passion. Specifically, we found that most studies focused on certain types of passion (e.g., developing; Drnovsek et al., 2016; Mueller et al., 2017), and this one-sided utilization restricted our understanding of how inventing, founding, harmonious, or obsessive passion relate to firm performance. In this context, Mueller et al. (2017) called for an investigation on the impact of other types of entrepreneurial passion on firm performance.

Moreover, the findings in the literature are contradictory. On the one hand, Ho and Pollack (2014) found a positive influence of harmonious passion on total business income. They also found that obsessive passion is negatively related to total business income. Even though both relationships were indirect, it is noteworthy that they asserted and found different performance outcomes of the two types of passion. On the other hand, the regression results of Sirén et al. (2016) show that both harmonious and obsessive passion have insignificant relationships with sales and profit growth. Although Sirén et al. (2016) did not hypothesize these direct relationships, the contradictory findings between Ho and Pollack (2014) and Sirén et al. (2016) provide important implications for future research. The difference between these two studies might have emerged from their different natures of data collection. Ho and Pollack (2014) utilized self-reported subjective performance data from the United States of America (USA) and Sirén et al. (2016) collected secondary data of sales and profit growth from Finland. The different empirical results between Ho and Pollack (2014) and Sirén et al. (2016) suggest scholars should clarify the relationships between the dualistic models of passion and 
firm performance. To advance our understanding of the entrepreneurial passion-firm performance relationship and clarify the contradictory findings of the dualistic models of passion-firm performance relationship, future scholars should examine different types of passion, apply diverse boundary conditions, and develop more nuanced theoretical arguments.

Second, based on the arguments that each type of passion is linked to idiosyncratic outcomes (Cardon et al., 2009; Vallerand et al., 2003), we suggest studying specific mediators that associate different types of passion and firm performance. Drnovsek et al. (2016) explained that "looking at specific types of entrepreneurial passion is important because different roles and activities entrepreneurs engage in may elicit different types of passion that are uniquely associated with outcomes of interest" (p. 206). Moreover, Strese et al. (2018) emphasized that we need to understand how various forms of passion are linked to respective outcomes. Accordingly, it is important to identify mechanisms between passion and firm performance. In meta-analyses, scholars have found that different outcomes corresponded with different types of passion (Curran et al., 2015; Pollack et al., 2020). These different outcomes could be utilized as mediators to understand the unique antecedent roles of passion on performance. For instance, one possible future research opportunity could be examining the founding passion of entrepreneurs in the pre-launch or early-stage firms. Founding passion indicates one's central identity and positive emotion toward "establishing a venture for commercializing and exploiting opportunities" (Cardon et al., 2009, p. 516) and has been related to creativity, persistence (Cardon et al., 2013), and entrepreneurial intentions (Biraglia $\&$ Kadile, 2017). Based on our systematic review, founding passion did not receive much attention from scholars compared to other forms of passion. As in the case of other types of passion, there may be other important factors that influence the founding passion-firm performance relationship. Hence, it would be of great importance to investigate specific mediators behind the relationship between founding passion and firm performance.

Scholars need to posit that passion alone is not enough to predict firm performance and requires an appropriate examination of boundary conditions and mechanisms. Even for passionate entrepreneurs, managing a firm can create pressures on time and resources, increases uncertainty, and be detrimental to personal well-being (Cardon et al., 2012). Accordingly, potential research opportunities in this area would be examining boundary conditions that could alleviate those barriers of entrepreneurs and ignite the passion-performance relationship. For instance, entrepreneurs in collectivistic cultures may receive strong psychological support from family and attain a safety net from their network (Lee et al., 2019), which might magnify the effects of passion on firm performance.

Third, we could increase our understanding of entrepreneurial passion by closely matching the arguments with the measurement of passion. Scholars have utilized the logic from overall entrepreneurial passion, citing several frameworks and used measurements of specific passion to empirically test their models. To enable the advancement of the literature, we should match the measures we use with established theory. For example, scholars using Cardon et al.'s (2009) framework of entrepreneurial passion to develop hypotheses should employ Cardon et al.'s (2013) survey items to test their theoretical models. Scholars have theorized using the term 'entrepreneurial passion' in their hypotheses but measured the passion differently. Some have built theoretical arguments based on overall entrepreneurial passion and utilized specific measures to operationalize entrepreneurial passion: harmonious passion (Murnieks et al., 2014), inventing passion (Huyghe et al., 2016), founding passion (Biraglia \& Kadile, 2017), developing passion (Mueller et al., 2017) and inventing, founding passion (Gielnik et al., 2015). The above-mentioned papers provided justifications of the utilization of specific measures and explained their limitations within discussion parts. For instance, Gielnik et al. (2015) justified the use of inventing and founding passion survey items to capture overall entrepreneurial passion, arguing that their sample of entrepreneurs are in the prelaunch stage, and Mueller et al. (2017) explained the use of developing passion to measure entrepreneurial passion because the entrepreneurs in their sample are "operating established firms, rather than working through the startup or founding process" (p. 268). Although these scholarly works have created an important body of knowledge, we could benefit by fitting the overall arguments and measurements to accelerate the progression of the field. A careful approach of matching the theoretical arguments and measurements would highly promote the advancement of entrepreneurial passion literature.

Fourth, the application of entrepreneurial passion in diverse cultural settings is needed. From 63 journal publications that we reviewed, 9 articles are conceptual and 54 are empirical. From those empirical papers, we listed countries where data on entrepreneurial passion have been collected and counted the number of times those countries have been chosen (Table 3): USA (23 times), Germany (11 times), Finland (4 times), Sweden (3 times), Australia (3 times), China (3 times), Belgium (2 times), Italy (2 times), and other countries were utilized once (Canada, Mexico, Brazil, Slovenia, Switzerland, Netherlands, Spain, Portugal, Russia, Hungary, Israel, Iran, and Singapore). Essen- 
tially, many scholars have called for employing entrepreneurial passion in various cultural contexts (e.g., Murnieks et al., 2020; Stenholm \& Renko, 2016; Strese et al., 2018). Applying diverse types of entrepreneurial passion in less studied countries and cultural settings would push the literature further. Moreover, we believe contextualized studies that establish country- or cultural-specific hypotheses and empirical examination within those settings would promote a fine-grained understanding of the entrepreneurship phenomenon (Lee et al., 2019; Miller, 2011).

Fifth, scholars should choose the type of passion (e.g., entrepreneurial passion, dualistic model of passion, work passion, and perceived passion) based on theoretical justifications and contextual appropriateness. Because passion is a domain-specific concept (Cardon et al., 2009; Vallerand et al., 2003), understanding 'passion for what' is a fundamental conclusion in the literature (Cardon, Glauser et al., 2017; Murnieks et al., 2014; Strese et al., 2018). Accordingly, focusing on the domain and research questions would help in having an appropriate application of the suitable frameworks for passion.

It is critical to mention that frameworks should be integrated in research studies with suitable theoretical justifications. Although the dualistic model of passion (Vallerand et al., 2003) and entrepreneurial passion (Cardon et al., 2009) share similarities like affection and identification as the core components of passion, they are different in their approach toward entrepreneurship and internalization (Collewaert et al., 2016; Ho \& Pollack, 2014). First, the dualistic model of passion takes a broad approach toward entrepreneurship. Most scholars study entrepreneurs' overall passion for entrepreneurial activities (e.g., Ho \& Pollack, 2014), and entrepreneurial passion focuses on specific roles of entrepreneurs such as inventing, developing, and founding (Cardon et al., 2009). Second, the dualistic model of passion considers how entrepreneurial activities are internalized in one's identity (Vallerand et al., 2003), and entrepreneurial passion is related to salient identity toward the roles of entrepreneurs (Cardon et al., 2009). Researchers should consider these differences and integrate frameworks of passion and empirical models with the appropriate theoretical rationale.

We also emphasize that even different types of passion from the same frameworks should be carefully distinguished based on theory and the research question being studied before their inclusion in theoretical models. While Vallerand et al. (2003) introduced the dualistic model of passion and suggested two types of passion (i.e., harmonious and obsessive passion), these two are different types of passion that do not necessarily have to be examined in the same model. Harmonious and obsessive passion are theoretically different in terms of internalization and behavior- al persistence toward a particular domain (Vallerand et al., 2003). Although they are rooted in the same framework, these two types are two independent variables, and scholars should probe whether they are continuum or orthogonal

Table 3

Summary of entrepreneurial passion research by country

\begin{tabular}{ccc}
\hline Cluster & Country & Study \\
\hline \multirow{3}{*}{ America } & USA & 23 \\
& Canada & 1 \\
& Mexico & 1 \\
& Brazil & 1 \\
\hline & Germany & 11 \\
& Finland & 4 \\
Europe & Sweden & 3 \\
& Belgium & 2 \\
& Italy & 2 \\
& Slovenia & 1 \\
& Switzerland & 1 \\
& Netherlands & 1 \\
& Spain & 1 \\
& Portugal & 1 \\
& Russia & 1 \\
& Hungary & 1 \\
\hline Oceania & China & 3 \\
& Israel & 1 \\
& Iran & 1 \\
& Singapore & 1 \\
\hline
\end{tabular}

constructs. They share theoretical similarities; both types attain strong inclinations toward a domain that people love. Most of the empirical correlations in previous studies were moderately high $(r=.48$ : Murnieks et al., 2020; $r=.44$ : Stroe et al., 2020). Scholars propose that the dualistic model of passion is not a unidimensional continuum construct but one that includes two disparate types of passion (Philippe et al., 2019). Second, because the dualistic model of passion is a domain-specific concept, harmonious and obsessive passion are not orthogonal constructs where both could score high on the same domain. In other words, when studying passion for one specific domain, an individual cannot have high levels of both harmonious and obsessive passion. Therefore, we emphasize that the decision between types of passion should be based on theoretical arguments and 
research questions.

Although most passion studies employ one framework of passion to answer their research questions, Huyghe et al. (2016) applied two different frameworks (e.g., obsessive passion and inventing passion) to introduce the concept of passion orchestra. Passion orchestra refers to "the intraindividual coexistence and interplay of entrepreneurial passion and passions for other non-entrepreneurial roles" (Huyghe et al., 2016, p. 345). While it is interesting and important, this approach should be taken carefully because it can be a baffling concept for readers to grasp that there can be simultaneous existence of multiple forms of passion. For instance, Huyghe et al. (2016) justified matching two different types of passion by providing a context of academia where researchers could have both obsessive passion for scientific research and entrepreneurial passion for inventing roles. Likewise, a contextual rationalization is critical for considering which types of passion would be appropriate to apply when studying passion orchestra. Also, scholars who plan to examine this stream of research could utilize polynomial regression and response surface methodology to advance our understanding of the fit between multiple types of passion.

Lastly, the terminologies of passion need to be clarified in future entrepreneurship research. As we attempted to synthesize the findings of entrepreneurial passion studies, multiple terminologies have been used for similar concepts, which might have brought confusion to the readers. For instance, scholars have used the term 'entrepreneurial passion' to refer to different domains of passion: 'harmonious entrepreneurial passion' (Murnieks et al., 2020) and 'perceived entrepreneurial passion' (Davis et al., 2017). It is important to use a unified terminology when referring to the same construct. In order to clarify the confusion, we suggest that scholars use exact terms established in the seminal papers of passion to advance the entrepreneurial passion literature.

\section{Conclusion}

In this paper, we attempted to compile what has been studied in the entrepreneurial passion literature and capture the main research opportunities in this area. Our systematic review advances the entrepreneurial passion literature by thoroughly synopsizing published works on different frameworks of passion in the entrepreneurship field. We summarized the findings based on four main conceptualizations of passion: passion for work, the dualistic model of passion, entrepreneurial passion, and perceived passion. Moreover, we suggested detailed research opportunities for each framework and the entrepreneurial passion literature in general. Specifically, we reviewed 63 journal publications between 2001 and 2020 and detected six essential research gaps in the literature. First, the research stream on the relationship between entrepreneurial passion and firm performance needs further advancement, primarily focusing on various frameworks of passion. Second, idiosyncratic mediators that link each type of passion and performance need to be examined. Third, theoretical frameworks and measurements of passion need to be thoroughly matched to advance the literature. Fourth, empirical studies of entrepreneurial passion should be conducted in diverse cultural settings. Fifth, each framework of passion should be studied based on theoretical and contextual justifications. Lastly, using exact terminologies suggested in seminal papers is of critical importance for establishing consensus among researchers and the advancement of theories.

\section{References}

Anderson, B. S., Eshima, Y., \& Hornsby, J. S. (2019). Strategic entrepreneurial behaviors: Construct and scale development. Strategic Entrepreneurship Journal, 13(2), 199-220.

Baker, T., \& Nelson, R. E. (2005). Creating something from nothing: Resource construction through entrepreneurial bricolage. Administrative Science Quarterly, 50(3), 329-366.

Baum, J. R., \& Locke, E. A. (2004). The relationship of entrepreneurial traits, skill, and motivation to subsequent venture growth. Journal of Applied Psychology, 89(4), 587-598.

Baum, J. R., Locke, E. A., \& Smith, K. G. (2001). A multidimensional model of venture growth. Academy of Management Journal, 44(2), 292-303.

Biraglia, A., \& Kadile, V. (2017). The role of entrepreneurial passion and creativity in developing entrepreneurial intentions: Insights from American homebrewers. Journal of Small Business Management, 55(1), 170188.

Bird, B. J. (1989). Entrepreneurial behavior. Scott Foresman.

Boone, S., Andries, P., \& Clarysse, B. (2020). Does team entrepreneurial passion matter for relationship conflict and team performance? On the importance of fit between passion focus and venture development stage. Journal of Business Venturing, (35)5, 105984.

Breugst, N., Domurath, A., Patzelt, H., \& Klaukien, A. (2012). Perceptions of entrepreneurial passion and employees' commitment to entrepreneurial ventures. Entrepreneurship Theory and Practice, 36(1), 171-192.

Campos, H. (2017). Impact of entrepreneurial passion on entrepreneurial orientation with the mediating role of 
entrepreneurial alertness for technology-based firms in Mexico. Journal of Small Business and Enterprise Development, 24(2), 353-374.

Cardon, M. S. (2008). Is passion contagious? The transference of entrepreneurial passion to employees. Human Resource Management Review, 18(2), 77-86.

Cardon, M. S., Foo, M. D., Shepherd, D., \& Wiklund, J. (2012). Exploring the heart: Entrepreneurial emotion is a hot topic. Entrepreneurship Theory and Practice, 36(1), 1-10.

Cardon, M. S., Glauser, M., \& Murnieks, C. Y. (2017). Passion for what? Expanding the domains of entrepreneurial passion. Journal of Business Venturing Insights, 8, 24-32.

Cardon, M. S., Gregoire, D. A., Stevens, C. E., \& Patel, P. C. (2013). Measuring entrepreneurial passion: Conceptual foundations and scale validation. Journal of Business Venturing, 28(3), 373-396.

Cardon, M. S., \& Kirk, C. P. (2015). Entrepreneurial passion as mediator of the self-efficacy to persistence relationship. Entrepreneurship Theory and Practice, 39(5), 1027-1050.

Cardon, M. S., Mitteness, C., \& Sudek, R. (2017). Motivational cues and angel investing: Interactions among enthusiasm, preparedness, and Commitment. Entrepreneurship Theory and Practice, 41(6), 1057-1085.

Cardon, M. S., Post, C., \& Forster, W. R. (2017). Team entrepreneurial passion: Its emergence and influence in new venture teams. Academy of Management Review, 42(2), 283-305.

Cardon, M. S., Wincent, J., Singh, J., \& Drnovsek, M. (2009). The nature and experience of entrepreneurial passion. Academy of Management Review, 34(3), 511532.

Cardon, M. S., Zietsma, C., Saparito, P., Matherne, B. P., \& Davis, C. (2005). A tale of passion: New insights into entrepreneurship from a parenthood metaphor. Journal of Business Venturing, 20(1), 23-45.

Chen, X. P., Yao, X., \& Kotha, S. (2009). Entrepreneur passion and preparedness in business plan presentations: A persuasion analysis of venture capitalists' funding decisions. Academy of Management Journal, 52(1), 199-214.

Collewaert, V., Anseel, F., Crommelinck, M., De Beuckelaer, A., \& Vermeire, J. (2016). When passion fades: Disentangling the temporal dynamics of entrepreneurial passion for founding. Journal of Management Studies, 53(6), 966-995.

Costa, S. F., Santos, S. C., Wach, D., \& Caetano, A. (2018). Recognizing opportunities across campus: The effects of cognitive training and entrepreneurial passion on the business opportunity prototype. Journal of Small Business Management, 56(1), 51-75.

Covin, J. G., \& Slevin, D. P. (1989). Strategic management of small firms in hostile and benign environments. Strategic Management Journal, 10(1), 75-87.

Curran, T., Hill, A. P., Appleton, P. R., Vallerand, R. J., \& Standage, M. (2015). The psychology of passion: A meta-analytical review of a decade of research on intrapersonal outcomes. Motivation and Emotion, 39(5), 631-655.

Dalborg, C., \& Wincent, J. (2015). The idea is not enough: The role of self-efficacy in mediating the relationship between pull entrepreneurship and founder passion-a research note. International Small Business Journal, 33(8), 974-984.

Davis, B. C., Hmieleski, K. M., Webb, J. W., \& Coombs, J. E. (2017). Funders' positive affective reactions to entrepreneurs' crowdfunding pitches: The influence of perceived product creativity and entrepreneurial passion. Journal of Business Venturing, 32(1), 90-106.

De Clercq, D., Honig, B., \& Martin, B. (2013). The roles of learning orientation and passion for work in the formation of entrepreneurial intention. International Small Business Journal, 31(6), 652-676.

de Mol, E., Cardon, M. S., de Jong, B., Khapova, S. N., \& Elfring, T. (2020). Entrepreneurial passion diversity in new venture teams: An empirical examination of shortand long-term performance implications. Journal of Business Venturing, 35(4), 105965.

de Mol, E., Ho, V. T., \& Pollack, J. M. (2018). Predicting entrepreneurial burnout in a moderated mediated model of job fit. Journal of Small Business Management, 56(3), 392-411.

Dess, G. G., \& Robinson Jr, R. B. (1984). Measuring organizational performance in the absence of objective measures: The case of the privately-held firm and conglomerate business unit. Strategic Management Journal, 5(3), 265-273.

Drnovsek, M., Cardon, M. S., \& Patel, P. C. (2016). Direct and indirect effects of passion on growing technology ventures. Strategic Entrepreneurship Journal, 10(2), 194-213.

Fisher, R., Maritz, A., \& Lobo, A. (2013). Obsession in entrepreneurs-towards a conceputalisation. Entrepreneurship Research Journal, 3(2), 207-237.

Fisher, R., Merlot, E., \& Johnson, L. W. (2018). The obsessive and harmonious nature of entrepreneurial passion. International Journal of Entrepreneurial Behavior and Research, 24(1), 22-40.

Gartner, W., Starr, J., \& Bhat, S. (1999). Predicting new venture survival: An analysis of "anatomy of a start- 
up." cases from Inc. Magazine. Journal of Business Venturing, 14(2), 215-232.

Gielnik, M. M., Spitzmuller, M., Schmitt, A., Klemann, D. K., \& Frese, M. (2015). "I put in effort, therefore I am passionate": Investigating the path from effort to passion in entrepreneurship. Academy of Management Journal, 58(4), 1012-1031.

Herrmann, P., \& Nadkarni, S. (2014). Managing strategic change: The duality of CEO personality. Strategic Management Journal, 35(9), 1318-1342.

Ho, V. T., \& Pollack, J. M. (2014). Passion isn't always a good thing: Examining entrepreneurs' network centrality and financial performance with a dualistic model of passion. Journal of Management Studies, 51(3), 433459.

Hou, F., Su, Y., Lu, M., \& Qi, M. (2019). Model of the entrepreneurial intention of university students in the Pearl River Delta of China. Frontiers in Psychology, 10, 916.

Hsu, D. K., Haynie, J. M., Simmons, S. A., \& McKelvie, A. (2014). What matters, matters differently: A conjoint analysis of the decision policies of angel and venture capital investors. Venture Capital, 16(1), 1-25.

Hubner, S., Baum, M., \& Frese, M. (2020). Contagion of entrepreneurial passion: Effects on employee outcomes. Entrepreneurship Theory and Practice, 44(6), 1112-1140.

Huyghe, A., Knockaert, M., \& Obschonka, M. (2016). Unraveling the "passion orchestra" in academia. Journal of Business Venturing, 31(3), 344-364.

Iyortsuun, A. S., Nmadu, M. T., Dakung, R., \& Gajere, M. C. (2019). Entrepreneurial passion and venture performance: A proposed framework. Management Research Review, 42(10), 1133-1147.

Kang, J. H., Matusik, J. G., Kim, T. Y., \& Phillips, J. M. (2016). Interactive effects of multiple organizational climates on employee innovative behavior in entrepreneurial firms: A cross-level investigation. Journal of Business Venturing, 31(6), 628-642.

Karimi, S. (2020). The role of entrepreneurial passion in the formation of students' entrepreneurial intentions. Applied Economics, 52(3), 331-344.

Kiani, A., Ali, A., Kanwal, S., \& Wang, D. (2020). How and when entrepreneurs' passion lead to firms' radical innovation: Moderated mediation model. Technology Analysis and Strategic Management, 32(4), 443-456.

Kier, A. S., \& McMullen, J. S. (2018). Entrepreneurial imaginativeness in new venture ideation. Academy of Management Journal, 61(6), 2265-2295.

Lee, Y., Howe, M., \& Kreiser, P. M. (2019). Organisational culture and entrepreneurial orientation: An orthogonal perspective of individualism and collectivism. Interna- tional Small Business Journal, 37(2), 125-152.

Li, J. J., Chen, X. P., Kotha, S., \& Fisher, G. (2017). Catching fire and spreading it: A glimpse into displayed entrepreneurial passion in crowdfunding campaigns. Journal of Applied Psychology, 102(7), 1075-1090.

Liu, D., Chen, X. P., \& Yao, X. (2011). From autonomy to creativity: A multilevel investigation of the mediating role of harmonious passion. Journal of Applied Psychology, 96(2), 294-309.

Locke, E. A. (1993). The traits of American business heroes. Manuscript in preparation, University of Maryland.

Lumpkin, G. T., \& Dess, G. G. (1996). Clarifying the entrepreneurial orientation construct and linking it to performance. Academy of Management Review, 21(1), 135-172.

Ma, H., \& Tan, J. (2006). Key components and implications of entrepreneurship: A 4-P framework. Journal of Business Venturing, 21(5), 704-725.

Marsh, H. W., Vallerand, R. J., Lafrenière, M. A. K., Parker, P., Morin, A. J., Carbonneau, N., Jowett, S., Bureau, J. S., Fernet, C., Guay, F., Salah Abduljabbar, A., \& Paquet, Y. (2013). Passion: Does one scale fit all? Construct validity of two-factor passion scale and psychometric invariance over different activities and languages. Psychological Assessment, 25(3), 796.

McCrae, R. R., \& Costa, P. T. (1987). Validation of the five-factor model of personality across instruments and observers. Journal of Personality and Social Psychology, 52(1), 81-90.

Milanesi, M. (2018). Exploring passion in hobby-related entrepreneurship. Evidence from Italian cases. Journal of Business Research, 92, 423-430.

Miller, D. (2011). Miller (1983) revisited: A reflection on EO research and some suggestions for the future. Entrepreneurship Theory and Practice, 35(5), 873-894.

Mitteness, C., Sudek, R., \& Cardon, M. S. (2012). Angel investor characteristics that determine whether perceived passion leads to higher evaluations of funding potential. Journal of Business Venturing, 27(5), 592-606.

Mueller, B. A., Wolfe, M. T., \& Syed, I. (2017). Passion and grit: An exploration of the pathways leading to venture success. Journal of Business Venturing, 32(3), 260-279.

Murnieks, C. Y., Cardon, M. S., \& Haynie, J. M. (2020). Fueling the fire: Examining identity centrality, affective interpersonal commitment and gender as drivers of entrepreneurial passion. Journal of Business Venturing, 35(1), 105909.

Murnieks, C. Y., Cardon, M. S., Sudek, R., White, T. D., \& Brooks, W. T. (2016). Drawn to the fire: The role of passion, tenacity and inspirational leadership in angel 
investing. Journal of Business Venturing, 31(4), 468484.

Murnieks, C. Y., Mosakowski, E., \& Cardon, M. S. (2014). Pathways of passion: Identity centrality, passion, and behavior among entrepreneurs. Journal of Management, 40(6), 1583-1606.

Newman, A., Obschonka, M., Moeller, J., \& Chandan, G. G. (2021). Entrepreneurial passion: A review, synthesis, and agenda for future research. Applied Psychology, 70(2), 816-860.

Obschonka, M., Moeller, J., \& Goethner, M. (2019). Entrepreneurial passion and personality: The case of academic entrepreneurship. Frontiers in Psychology, 9, 2697.

Oo, P. P., Allison, T. H., Sahaym, A., \& Juasrikul, S. (2019). User entrepreneurs' multiple identities and crowdfunding performance: Effects through product innovativeness, perceived passion, and need similarity. Journal of Business Venturing, 34(5), 105895.

Patel, P. C., Thorgren, S., \& Wincent, J. (2015). Leadership, passion and performance: A study of job creation projects during the recession. British Journal of Management, 26(2), 211-224.

Philippe, F. L., Vallerand, R. J., Beaulieu-Pelletier, G., Maliha, G., Laventure, S., \& Ricard-St-Aubin, J. S. (2019). Development of a dualistic model of sexual passion: Investigating determinants and consequences. Archives of Sexual Behavior, 48(8), 2537-2552.

Philippe, F. L., Vallerand, R. J., Houlfort, N., Lavigne, G. L., \& Donahue, E. G. (2010). Passion for an activity and quality of interpersonal relationships: The mediating role of emotions. Journal of Personality and Social Psychology, 98(6), 917-932.

Pollack, J. M., Ho, V. T., O’Boyle, E. H., \& Kirkman, B. L. (2020). Passion at work: A meta-analysis of individual work outcomes. Journal of Organizational Behavior, 41(4), 311-331.

Rauch, A., Wiklund, J., Lumpkin, G. T., \& Frese, M. (2009). Entrepreneurial orientation and business performance: An assessment of past research and suggestions for the future. Entrepreneurship Theory and Practice, 33(3), 761-787.

Reis, H. T., \& Aron, A. (2008). Love: What is it, why does it matter, and how does it operate? Perspectives on Psychological Science, 3(1), 80-86.

Rosenbusch, N., Brinckmann, J., \& Bausch, A. (2011). Is innovation always beneficial? A meta-analysis of the relationship between innovation and performance in SMEs. Journal of Business Venturing, 26(4), 441-457.

Ruskin, J., Seymour, R. G., \& Webster, C. M. (2016). Why create value for others? An exploration of social en- trepreneurial motives. Journal of Small Business Management, 54(4), 1015-1037.

Santos, S. C., \& Cardon, M. S. (2019). What's love got to do with it? Team entrepreneurial passion and performance in new venture teams. Entrepreneurship Theory and Practice, 43(3), 475-504.

Schenkel, M. T., Farmer, S., \& Maslyn, J. M. (2019). Process improvement in SMEs: The impact of harmonious passion for entrepreneurship, employee creative self-efficacy, and time spent innovating. Journal of Small Business Strategy, 29(1), 64-77.

Schulte-Holthaus, S. (2019). Passion and performance in entrepreneurial contexts: An interest-based approach. Journal of Entrepreneurship, 28(2), 201-222.

Schumpeter, J. A. (1951). Imperialism and social classes. Augustus M Kelley Pubs.

Schwens, C., Zapkau, F. B., Bierwerth, M., Isidor, R., Knight, G., \& Kabst, R. (2018). International entrepreneurship: A meta-analysis on the internationalization and performance relationship. Entrepreneurship Theory and Practice, 42(5), 734-768.

Shane, S., Drover, W., Clingingsmith, D., \& Cerf, M. (2020). Founder passion, neural engagement and informal investor interest in startup pitches: An fMRI study. Journal of Business Venturing, 35(4), 105949.

Shane, S., Locke, E. A., \& Collins, C. J. (2003). Entrepreneurial motivation. Human Resource Management Review, 13(2), 257-279.

Shepherd, D. A., Wennberg, K., Suddaby, R., \& Wiklund, J. (2019). What are we explaining? A review and agenda on initiating, engaging, performing, and contextualizing entrepreneurship. Journal of Management, 45(1), 159-196.

Sirén, C., Patel, P. C., \& Wincent, J. (2016). How do harmonious passion and obsessive passion moderate the influence of a CEO's change-oriented leadership on company performance? Leadership Quarterly, 27(4), 653-670.

Stenholm, P., \& Nielsen, M. S. (2019). Understanding the emergence of entrepreneurial passion: The influence of perceived emotional support and competences. International Journal of Entrepreneurial Behavior and Research, 25(6), 1368-1388.

Stenholm, P., \& Renko, M. (2016). Passionate bricoleurs and new venture survival. Journal of Business Venturing, 31(5), 595-611.

Stephan, U. (2018). Entrepreneurs' mental health and well-being: A review and research agenda. Academy of Management Perspectives, 32(3), 290-322.

Sternberg, R. J. (1986). A triangular theory of love. Psychological Review, 93(2), 119-135. 
Strese, S., Keller, M., Flatten, T. C., \& Brettel, M. (2018). CEOs' passion for inventing and radical innovations in SMEs: The moderating effect of shared vision. Journal of Small Business Management, 56(3), 435-452.

Stroe, S., Parida, V., \& Wincent, J. (2018). Effectuation or causation: An fsQCA analysis of entrepreneurial passion, risk perception, and self-efficacy. Journal of Business Research, 89, 265-272.

Stroe, S., Sirén, C., Shepherd, D., \& Wincent, J. (2020). The dualistic regulatory effect of passion on the relationship between fear of failure and negative affect: Insights from facial expression analysis. Journal of Business Venturing, 35(4), 105948.

Stroe, S., Wincent, J., \& Parida, V. (2018). Untangling intense engagement in entrepreneurship: Role overload and obsessive passion in early-stage entrepreneurs. Journal of Business Research, 90, 59-66.

Swann, W. B., Gómez, Á., Seyle, D. C., Morales, J., \& Huici, C. (2009). Identity fusion: The interplay of personal and social identities in extreme group behavior. Journal of Personality and Social Psychology, 96(5), 9951011.

Thorgren, S., \& Wincent, J. (2015). Passion and habitual entrepreneurship. International Small Business Journal, 33(2), 216-227.

Tranfield, D., Denyer, D., \& Smart, P. (2003). Towards a methodology for developing evidence-informed management knowledge by means of systematic review. British Journal of Management, 14(3), 207-222.

Türk, S., Zapkau, F. B., \& Schwens, C. (2020). Prior entrepreneurial exposure and the emergence of entrepreneurial passion: The moderating role of learning orientation. Journal of Small Business Management, 58(2), 225-258.

Unger, J. M., Rauch, A., Frese, M., \& Rosenbusch, N. (2011). Human capital and entrepreneurial success: A meta-analytical review. Journal of Business Venturing, 26(3), 341-358.

Vallerand, R. J. (2015). The psychology of passion: A dualistic model. Oxford University Press.

Vallerand, R. J., Blanchard, C., Mageau, G. A., Koestner, R., Ratelle, C., Léonard, M., Gagné, M., \& Marsolais, J. (2003). Les passions de l'ame: On obsessive and harmonious passion. Journal of Personality and Social Psychology, 85(4), 756.

Warnick, B. J., Murnieks, C. Y., McMullen, J. S., \& Brooks, W. T. (2018). Passion for entrepreneurship or passion for the product? A conjoint analysis of angel and VC decision-making. Journal of Business Venturing, 33(3), 315-332.
Xiao, Y., Dowejko, M. K., Au, K., \& Hsu, A. J. (2020). "Jack-of-all-trades" with passion: Keener to pursue startup in a team?. Journal of Small Business Management, 58(4), 806-833.

Yitshaki, R., \& Kropp, F. (2016). Entrepreneurial passions and identities in different contexts: A comparison between high-tech and social entrepreneurs. Entrepreneurship and Regional Development, 28(3-4), 206233.

Zhao, H., \& Seibert, S. E. (2006). The big five personality dimensions and entrepreneurial status: A meta-analytical review. Journal of Applied Psychology, 91(2), 259271.

Zhao, H., Seibert, S. E., \& Lumpkin, G. T. (2010). The relationship of personality to entrepreneurial intentions and performance: A meta-analytic review. Journal of Management, 36(2), 381-404. 
Appendix

Literature Review of Entrepreneurial Passion

\begin{tabular}{|c|c|c|c|c|c|}
\hline Authors & Year & Journal & $\begin{array}{l}\text { Type of } \\
\text { Research }\end{array}$ & Type of Passion & Findings \\
\hline Newman et al. ${ }^{1}$ & 2021 & $\mathrm{AP}$ & Conceptual & All types & $\begin{array}{l}\text { Authors review the literature on entrepreneurial passion and summari- } \\
\text { ze the antecedents and outcomes of different types of entrepreneurial } \\
\text { passion. }\end{array}$ \\
\hline Boone et al. & 2020 & JBV & Empirical & $\begin{array}{l}\text { Entrepreneurial } \\
\text { passion }\end{array}$ & $\begin{array}{l}\text { In the commercialization stage, poly-focal team entrepreneurial passion } \\
\text { is better at achieving high team performance through reduced rela- } \\
\text { tionship conflict than mono-focal team entrepreneurial passion for either } \\
\text { inventing or founding. }\end{array}$ \\
\hline De Mol et al. & 2020 & JBV & Empirical & $\begin{array}{l}\text { Entrepreneurial } \\
\text { passion }\end{array}$ & $\begin{array}{l}\text { New venture teams' average passion is not associated with performance. } \\
\text { Entrepreneurial passion diversity (i.e., intensity separation) negatively } \\
\text { influences the quality of the business idea and entrepreneurial passion } \\
\text { diversity (i.e., focus variety) negatively impacts the amount of funding } \\
\text { that teams will receive. }\end{array}$ \\
\hline Hubner et al. & 2020 & ETP & Empirical & $\begin{array}{l}\text { Entrepreneurial } \\
\text { passion }\end{array}$ & $\begin{array}{l}\text { Authors empirically studied the contagion effect of entrepreneurial } \\
\text { passion. Specifically, they found that entrepreneurs' passion experience } \\
\text { (i.e., merging all passion domains) positively impacts employee affective } \\
\text { commitment through employee passion response. When they examined } \\
\text { the types of passion separately, only developing passion would lead to } \\
\text { employee affective commitment through employee passion response. }\end{array}$ \\
\hline Karimi & 2020 & $\mathrm{AE}$ & Empirical & $\begin{array}{l}\text { Entrepreneurial } \\
\text { passion }\end{array}$ & $\begin{array}{l}\text { Based on the theory of planned behavior, the authors found that univer- } \\
\text { sity students' passion for inventing positively increases entrepreneurial } \\
\text { intentions through either attitudes toward entrepreneurship or perceived } \\
\text { behavioral control. }\end{array}$ \\
\hline Kiani et al. & 2020 & TASM & Empirical & $\begin{array}{l}\text { Entrepreneurial } \\
\text { passion }\end{array}$ & $\begin{array}{l}\text { Authors examined the indirect influence of entrepreneurial passion on } \\
\text { radical innovation through exploratory learning. }\end{array}$ \\
\hline Murnieks et al. & 2020 & JBV & Empirical & $\begin{array}{l}\text { Dualistic model of } \\
\text { passion }\end{array}$ & $\begin{array}{l}\text { Authors studied the antecedents of entrepreneurial passion. Specifically, } \\
\text { entrepreneurial identity centrality leads to harmonious entrepreneurial } \\
\text { passion and affective interpersonal commitment drives obsessive en- } \\
\text { trepreneurial passion. Moreover, the authors examined the gender of } \\
\text { entrepreneurs as the moderator of both relationships. As a result, male } \\
\text { entrepreneurs positively strengthened both relationships. }\end{array}$ \\
\hline Shane et al. & 2020 & JBV & Empirical & Perceived passion & $\begin{array}{l}\text { Using fMRI, authors empirically found the causal relationship between } \\
\text { entrepreneurs' displayed passion and informal investors' interest. }\end{array}$ \\
\hline
\end{tabular}




\section{Stroe et al.}

2020

JBV

Empirical

Dualistic model of passion

Türk et al.

2020

JSBM

Empirical
Entrepreneurial passion

Xiao et al.

JSBM

Empirical

Entrepreneurial passion

\section{Hou et al.}

FP

Empirical

Iyortsuun et al

2019

MRB

Conceptual

Obschonka et al.

2019

Oo et al.

Santos \& Cardon

2019

ETP

Empirical

Schenkel et al.

2019

JSBS

Empirical

Schulte-Holthaus

2019

JOE

Stenholm \&

2019

IJEBR

Nielsen
Empirical

Empirical Entrepreneurial
passion passion Dualistic model of
passion

$$
\text { passion }
$$

Entrepreneurial passion

Dualistic model of

Perceived passion

ial

:
cal (NVTs with a higher score in one of the domains compared to the others); incomplete poly-focal (NVTs showing higher scores in two of the three domains of TEP); and complete poly-focal (NVTs showing no differences between the scores of the three domains)" (p. 10). TEP for founding is not empirically related to team performance.

Employees' harmonious passion for being entrepreneurial positively influences them to spend more time thinking about new ideas, which then leads them to suggest increased number of job-related innovative ideas. Moreover, employees' creative self-efficacy negatively moderates the relationship between harmonious passion and time spent on innovating.

Author proposes a framework to understand passion in entrepreneurial contexts.

\section{All types}

Entrepreneurial passion preneurial passion and this relationship is strengthened by entrepreneurial experience.

Entrepreneurs' fear of failure manifests negative affect and harmonious passion reduces this influence. However, obsessive passion showed both positive and negative moderating effects in two different studies. and entrepreneurial experience) positively influences them to nurture entrepreneurial passion and learning orientation strengthens these relationships.

Employees' skill variety positively impacts them to form a team and this influence is strengthened by employees' developing passion.

University students' entrepreneurial passion leads to high levels of entrepreneurial intentions through entrepreneurial self-efficacy.

preneurial passion on performance through diverse mediators.

Researchers' harmonious entrepreneurial passion is positively associated ceived passion.

Team entrepreneurial passion (TEP) for inventing and developing increa- 


\section{Costa et al.}

2018

JSBM

Empirical

Entrepreneurial passion

De Mol et al.

JSBM

Empirical

Fisher et al.

2018

IJEBR

Empirical

Milanesi

2018

JBR

Empirical

Strese et al.

JSBM

Stroe, Parida, \&

2018

Wincent

\section{Stroe, Wincent, \&}

2018

JBR

Empirical

Warnick et al.
2018

\section{JBV}

Dualistic model of passion

Empirical

Empirical

Entrepreneurial
passion

Dualistic model of passion

Empirical

Perceived passion
Dualistic model of passion

Dualistic model of passion All types
Intensive positive feelings toward developing, inventing, and founding role identities positively moderate the impact of cognitive entrepreneurial training on the accuracy of the business opportunity recognition.

Entrepreneurs' job fit leads to higher burnout through obsessive passion. Destiny beliefs about work strengthen the impact of job fit on obsessive passion. Harmonious passion is negatively associated with burnout.

Entrepreneurs' obsessive passion leads to sustained commitment and harmonious passion influences entrepreneurs to perceive themselves as successful through resilience.

Author suggests a hobby-related entrepreneurial process that explains the manifestation of entrepreneurial passion. Entrepreneurs enjoy domain passion (e.g., hobby) and accumulate knowledge and skills related to the domain. With increased exposure and interactions with people in the domain, entrepreneurs find opportunities and nurture entrepreneurial passion to start a company and commercialize the product.

CEOs' passion for inventing positively increases radical innovation in SMEs and shared vision moderates this relationship.

Entrepreneurs with harmonious passion make effectual decision making when they have high self-efficacy or perceive high risk in the environment. Entrepreneurs with obsessive passion make causal decision making when they have low risk perception of the environment. In other words, entrepreneurs implement different entrepreneurial decision-making logic depending on their types of passion under certain conditions.

Role overload develops nascent entrepreneurs' obsessive passion. Goal challenge and achieved progress strengthen the impact of role overload on obsessive passion.

Angel investors and venture capitalists perceive both entrepreneurial passion and passion for product as critical factors for investment decisions. Entrepreneurs' openness to feedback positively moderates both types of passion toward funding potential. Interestingly, there is a three-way interaction among investing experience of investors, openness to feedback, and entrepreneurial passion toward funding potential. Passion for product also demonstrates a three-way interaction with entrepreneurial experience of investors and openness to feedback toward funding potential. However, combination of entrepreneurial passion and passion for product does not predict funding potential. 
Biraglia \& Kadile

2017

JSBM

Empirical

Campos

2017

JSBED

Empirical

Cardon, Glauser

et al.

Cardon, Mitteness

2017

et al.

Cardon,Post et al.

2017

AMR

Conceptual

Entrepreneurial passion

\section{Davis et al}

Li et al.

2017

JAP

Empirical

Perceived passion

Mueller et al.

$2017 \quad$ JBV $\quad$ Empirical

Entrepreneurial passion

Entrepreneurial passion

All types

Perceived passion
Evaluations of funding decisions by angel investors are positively associated with entrepreneurs' level of preparedness. When entrepreneurs commit personal money to their idea, prepared entrepreneurs' chance of obtaining positive evaluations on funding has increased. In other words, angel investors favor prepared entrepreneurs with personal financial commitment in their idea.

Team passion diversity would positively influence the formation of team entrepreneurial passion (i.e., "the level of shared intense positive feelings for a collective team identity that is high in identity centrality for the NVT", p. 286). Moreover, team entrepreneurial passion impacts diverse individual- and team-level outcomes like new venture team performance, quality of new venture team processes, and individual entrepreneurial passion.

Entrepreneurial passion perceived by funders positively moderates the relationship between product creativity and positive affective reactions. Authors empirically find a negative influence of perceived entrepreneurial passion on funders' investment decisions and predicted success.

Entrepreneurs' displayed passion on crowdfunding video expands the enthusiasm of viewers, which in turn increases funding amount and social media exposure. Project innovativeness perceived by viewers also invigorates the displayed passion-funding amount and displayed passion-social media exposure relationships.

Entrepreneurs' passion for developing indirectly increases firm performance through 1) self-regulatory mode (locomotion and assessment) and 2) grit. 
Collewaert et at.

Drnovsek et al.

SEJ

Huyghe et al.

2016

JBV

Empirical

Kang et al.

2016

JBV

Empirical

Entrepreneurial passion

Murnieks et al.

2016

JBV

Empirical

Dualistic model of passion

Ruskin et al.

JSBM

Empirical

All types

Sirén et al.

2016

Empirical

Dualistic model of passion

Stenholm \& Renko

2016

JBV

Empirical

Yitshaki \& Kropp

2016

Empirical

\section{Entrepreneuria passion}

All types
Entrepreneurial passion for founding diminishes in the course of time. Specifically, intensive positive feelings decrease over time and identity centrality remains stable.

Founder CEOs' passion for developing directly impacts sales and employee growth. Moreover, goal commitment mediates the relationship between developing passion and venture growth.

Inventing passion increases spin-off and start-up intentions. Entrepreneurial self-efficacy indirectly influences inventing passion-intentions relationship. Moreover, obsessive passion positively influences spin-off intentions and affective organizational commitment mediates this influence. As the core findings of the paper, inventing and obsessive passions 'orchestrate' together to impact spin-off intentions.

Authors find an antecedent (i.e., organizational innovative climate) and an outcome (i.e., employees' innovative behavior) of entrepreneurial passion for inventing. Proactive climate positively moderates the relationship between innovative climate and inventing passion and risk-taking climate increases the influence of inventing passion toward innovative behavior.

Perceived obsessive passion and tenacity of entrepreneurs positively influence the funding potential from angel investors. Moreover, a three-way interaction among entrepreneurial experience of angel investors, perceived obsessive passion, and tenacity of entrepreneurs positively predicts funding potential from angel investors.

Entrepreneurial passion act as an emotional antecedent of self-oriented motives (i.e., achievement, autonomy, relatedness, and influence) of social entrepreneurs.

Harmonious passion positively moderates the relationship between CEOs' change-oriented leadership and firm performance. Authors empirically find that both harmonious and obsessive passions are not related to sales and profit growth.

Inventing and developing passion indirectly influence new venture survival through bricolage. However, passion for founding neither fosters bricolage nor new venture survival.

High-tech entrepreneurs' passion encompasses "a strong challenge to lead a meaningful activity" and social entrepreneurs' passion embodies "a desire to make a mark" (p. 206). 
Cardon \& Kirk

Dalborg \& Wincent

2015

ETP

Empirical

2015

ISBJ

Empirical

Gielnik et al.

2015

AMJ

Empirical

Thorgren \&

Wincent

2015

ISBJ

Empirical

Dualistic model of passion

\section{Ho \& Pollack}

2014

JMS

Empirical

Dualistic model of passion

Hsu et al.

Murnieks et al.

2014

Cardon et al.

2013

De Clercq et al.

2013
Entrepreneurial passion

Dualistic model of passion

Entrepreneurial passion
JOM

Empirical

JBV

Empirical

2014

VC

Empirical

All types

Dualistic model of passion

Entrepreneurial passion

Empirical

Passion for work
Authors theorize and empirically find that entrepreneurial self-efficacy indirectly increases persistence through inventing and founding passion.

Entrepreneurs who are "being pulled toward opportunities to start a business" indirectly nurture entrepreneurial passion through self-efficacy (p. 974).

Entrepreneurial effort ("intensity of work" toward entrepreneurship-related works) positively manifests entrepreneurial passion. Authors also argue the mediation effect of new venture progress that effort leads to progress of new venture and also eventually forms entrepreneurial passion. Moreover, free choice of entrepreneurs moderates the effort-progress-passion relationship.

Obsessive entrepreneurial passion is positively related to habitual entrepreneurship (i.e., "exposed to multiple venture engagements"). Specifically, obsessive passion is related to both serial (i.e., "engaged in a previous start-up") and portfolio entrepreneurship (i.e., "started another business while running at least one other company", p. 219). However, harmonious passion only impacts portfolio entrepreneurship among habitual entrepreneurship types.

On the one hand, harmonious entrepreneurial passion indirectly impacts referral and total business income through increased out-degree centrality (i.e., searching for others). On the other hand, obsessive entrepreneurial passion negatively influences referral and total business income through decreased in-degree centrality (i.e., unsociable).

Passion is a significant factor that predicts funding potentials. Specifically, angel investors put more importance on affective passion of entrepreneurs than venture capitalists when making investment decisions.

Harmonious passion leads to both entrepreneurial behavior and self-efficacy.

Authors developed the survey instruments for entrepreneurial passion. Moreover, they empirically found that entrepreneurial passion for founding is associated with creativity and persistence. Entrepreneurial passion for developing is positively linked to absorption.

Passion for work is positively associated with entrepreneurial intentions. Passion for work also strengthens the perceived ability-entrepreneurial intentions and perceived attractiveness-entrepreneurial intentions relationships. 
Fisher et al.

2013

ERJ

Empirical

Dualistic model of passion

Breugst et al.

2012

ETP

Empirical

Entrepreneurial passion

Mitteness et al.

2012

JBV

Empirical

Perceived passion

Cardon et al.

AMR

Conceptual

Entrepreneurial passion

\section{Chen et al.}

2009

AMJ

2008

HRMR

Conceptual

2006

JBV

Conceptual

Ma \& Tan

Cardon et al.

2005

JBV

Conceptual

2004
JAP
Empirical

Perceived passion

All types

All types

All types

Baum \& Locke
Journal of Small Business Strategy / Vol. 31, No. 3 (2021/122-14
inical literature, the authors propose a new framework

of entrepreneurial obsession. They explain that entrepreneurs experience high levels of obsession with their firms. Moreover, they argue that obsessive entrepreneurs achieve aimed performance but might attain anxiety issues.

Perceived inventing and developing passion indirectly form employees' affective commitment through positive affect. Goal clarity mediates the relationship between developing passion and affective commitment.

Perceived founding passion negatively impacts affective commitment through low positive affect.

Passion perceived by angel investors positively influences funding potentials. Moreover, angel investors' characteristics like older age, higher intuition, openness, and motivation toward mentors strengthen the perceived passion-funding potential relationship. However, angels who are extraverted and promotion-focused negatively impact the relationship.

Authors propose the theory of entrepreneurial passion and conceptualize three different role identities of entrepreneurial passion (i.e., founder, inventor, and developer). They also provide theoretical arguments of the direct impact of entrepreneurial passion on opportunity recognition, venture creation, and growth and the mediation influence of creative problem solving, persistence, and absorption in identity-specific activities.

Preparedness in presentations promotes funding potentials from venture capitalists as a perceived cognitive passion. However, perceived affective passion does not impact funding potentials.

Explain the contagion effect of entrepreneurial passion on employee passion through transformational leadership.

Authors theoretically argue that passion is one of the main components of entrepreneurship that leads to firm performance.

Entrepreneurial passion is related to both positive and negative results. For instance, entrepreneurial passion is positively associated with high levels of persistence and confidence during difficult times. However, it is also related to negative outcomes like relationship issues with spouse or parents due to the increased commitment toward their venture.

Entrepreneur-CEOs' passion for work is indirectly related to venture growth through communicated vision, goals, and self-efficacy. The direct impact of passion on venture growth is not supported. 
CEOs' passion for work indirectly leads to sales, employment, and profit growth through general competencies (i.e., organization and opportunity skill), specific competencies (i.e., industry and technical skill), motivation (i.e., vision, goals, and self-efficacy), and competitive strategies (i.e., differentiation through innovation and quality/service).

\footnotetext{
Note. AE = Applied Economics, AMJ = Academy of Management Journal, AMR = Academy of Management Review, AP = Applied Psychology, ERD = Entrepreneurship and Regional Development, ERJ = Entrepreneurship Research Journal, ETP = Entrepreneurship Theory and Practice, FP = Frontiers in Psychology, HRMR = Human Resource Management Review, IJEBR = International Journal of Entrepreneurial Behavior and Research, ISBJ = International Small Business Journal, JAP $=$ Journal of Applied Psychology, JBR = Journal of Business Research, JBV = Journal of Business Venturing, JVBI $=$ Journal of Business Venturing Insights, JMS = Journal of Management Studies, JOE = Journal of Entrepreneurship, JOM = Journal of Management, JSBED = Journal of Small Business and Enterprise Development, JSBM = Journal of Small Business Management, JSBS = Journal of Small Business Strategy, LQ = Leadership Quarterly, MRR $=$ Management Research Review, SEJ = Strategic Entrepreneurship Journal, TASM = Technology Analysis and Strategic Management, VC = Venture Capital.

1. Newman et al. (2021) was in press since 2019.
} 